\title{
Evaluation of pounding effects between reinforced concrete frames subjected to far-field earthquakes in terms of damage index
}

\author{
S. H. Hosseini ${ }^{1} \cdot$ H. Naderpour ${ }^{1} \cdot$ R. Vahdani $^{1} \cdot$ R. Jankowski ${ }^{2}$ D
}

Received: 28 April 2021 / Accepted: 13 October 2021 / Published online: 28 October 2021

(C) The Author(s) 2021

\begin{abstract}
In this paper, three different damage indexes were used to detect nonlinear damages in two adjacent Reinforced Concrete (RC) structures considering pounding effects. 2-, 4and 8-story benchmark RC Moment Resisting Frames (MRFs) were selected for this purpose with $60 \%, 75 \%$, and $100 \%$ of minimum separation distance and also without any inbetween separation gap. These structures were analyzed using the incremental dynamic analysis method under 44 far-field ground motion records. Comparison of the results between the MRFs with and without considering pounding effects show that collisions lead to a decrease in the values of coefficient of determination and the nonlinear damage occurs in lower seismic intensity. As a result, using the damage indexes, nonlinear damages can be detected during a specific seismic intensity. Moreover, considering a minimum separation distance leads to an increase in the coefficient of determination between the damage index and the maximum story drift ratio. Furthermore, due to pounding, shorter MRFs are damaged more significantly than the taller structures.
\end{abstract}

Keywords Reinforced concrete moment resisting frames $\cdot$ Structural pounding $\cdot$ Far-field earthquakes · Incremental dynamic analysis · Maximum story drift ratio $\cdot$ Damage index

\section{Introduction}

Structural pounding due to insufficient gaps may cause collisions between adjacent structures during earthquakes. If adjacent buildings, or bridge segments, are not separated suitably from each other, impact forces may cause serious damages even if structures are well designed (Miari et al. 2019, 2021; Rezaei et al. 2020). The first research work that explains possible dangers due to building pounding was performed by Anagnostopoulos (1988). Several reports showed that at least $15 \%$ of buildings were damaged due to the impact of

R. Jankowski

jankowr@pg.edu.pl

1 Faculty of Civil Engineering, Semnan University, Semnan, Iran

2 Faculty of Civil and Environmental Engineering, Gdansk University of Technology, ul. Narutowicza 11/12, 80-233 Gdansk, Poland 
adjacent buildings during the 1985 Mexico City earthquake (Rosenblueth and Meli 1986). Researchers used different numerical and experimental methods to simulate the problem of earthquake-induced pounding between adjacent buildings (Leibovich et al. 1996; Ruangrassamee and Kawashima 2001; DesRoches and Muthukumar 2002; Mahmoud and Jankowski 2009; Jankowski 2010; Yaghmaei-Sabegh and Jalali-Milani 2012; Barros et al. 2013; Sołtysik and Jankowski 2013; Naderpour et al. 2015; 2016; 2017; Kazemi et al. 2021a). A number of investigations were focused on comparison between different numerical models of pounding force during impact (see Mahmoud, et al. 2008; Muthukumar and DesRoches 2006, for example). Other studies concerned the experimental verification of the effectiveness of pounding force models in simulation of earthquake-induced structural interactions (Barros and Khatami 2013; Khatiwada et al. 2013). Some recent analyses were also focused on different pounding mitigation methods so as to reduce the negative effects of collisions during seismic excitations (see Kandemir-Mazanoglu and Mazanoglu 2017; Elwardany et al. 2021, for example).

A new equation to calculate the effective periods of inelastic buildings, based on ductility demand, which can be successfully applied for the determination of a minimum separation gap was proposed by Khatami et al. (2019). The results showed that using the proposed methods, the impacts between two adjacent buildings due to earthquake-induced structural pounding can be prevented by ensuring sufficient minimum separation gap. A new model for calculating impact force and energy dissipation, based on the coefficient of restitution and impact velocity, was proposed by Naderpour and Khatami (2015). To evaluate the accuracy of the suggested formula, the relationship between the selected coefficient of restitution and the calculated coefficient of restitution was compared. The results showed good accuracy in comparison with other formulas. A review of earthquake-induced pounding between adjacent buildings considering identification of parameters and soilstructure interaction issues was performed by Miari et al. (2019). The effects of pounding on fixed-base and base-isolated buildings were also examined. Based on the obtained results, directions of future research studies on structural pounding were recommended. The effect of the infill panels on the seismic pounding response of adjacent structures in series was studied by Elwardany et al. $(2017,2019)$. The results of the analysis showed that the existence of infill panels changes the seismic behavior of the structures during pounding under seismic excitation. The effect of using linear and nonlinear fluid viscous dampers on the seismic collapse capacities of adjacent structures prone to pounding was investigated by Kazemi et al. (2021b). The results demonstrated that the existence of dampers can substantially improve the seismic behavior of structures having a significant influence on their collapse capacities. The effects of pounding between two L-shaped asymmetric steel buildings under earthquake excitation were evaluated by Sołtysik and Jankowski (2016). The results indicated that these effects lead to both an increase and/or a decrease in the structural response. Moreover, torsional vibrations (due to eccentric pounding) were found to play an important role in the overall pounding-involved response of asymmetric steel buildings under earthquake excitations. Building damage due to structural pounding during earthquakes was studied by Sołtysik and Jankowski (2015). Steel asymmetric structures with a different number of stories were utilized for numerical analysis. Three-dimensional gap-friction elements were used for controlling pounding between buildings. The acceleration time histories of the El Centro earthquake were used in the numerical analysis. The results of the study clearly showed that pounding may substantially influence the response of steel buildings intensifying their damage during earthquakes. The influence of non-uniform earthquake excitation on the pounding-involved response of two buildings using nonlinear FEM analysis was investigated by Jankowski (2012). The obtained results showed 
that the non-uniform ground motion excitation may considerably influence the poundinginvolved behavior of buildings. The effect of different structural configurations on pounding-involved response of adjacent planar Reinforced Concrete (RC) building frames subjected to strong ground motions was examined by Efraimiadou et al. (2013a). The results showed that the effect of collisions of adjacent frames is unfavorable for most of the cases and, as a result, the structural pounding phenomenon is rather detrimental than beneficial. The effect of collisions between adjacent RC building frames under multiple earthquakes was investigated by Efraimiadou et al. (2013b). The effects of various parameters, such as maximum horizontal displacement of the top floor, ductility of columns, permanent displacements, and four different separation gaps, were considered. Based on the results, the behavior of adjacent structures was found to be strongly affected by multiple earthquakes and, for most of the cases, the seismic sequences appeared to be detrimental in comparison with the single seismic events. A new damage index for plane steel frames considering the strength and stiffness degradation under ground motion was proposed by Kamaris et al. (2013). Various parameters, including interaction between the axial force and the bending moment with low-cycle fatigue, were examined. The correlation of the proposed damage index showed good match with five well known indexes described in the literature. The accuracy of four different criteria to calculate the separation necessary to prevent seismic pounding between nonlinear hysteretic structural systems was evaluated by Lopez-Garcia and Soong (2009b). The results showed that the Double Difference Combination (DDC) rule is always more accurate than the Square Root of the Sum of the Squares (SRSS) rule in the case of linear systems. However, in the case of nonlinear hysteretic systems, none of the four implementations of the DDC rule was consistently more accurate than the SRSS rule. The accuracy of the DDC rule to predict the separation gap necessary to prevent seismic pounding between linear structural systems was examined by Lopez-Garcia and Soong (2009a). Damage assessment of adjacent buildings under earthquake loads, using input energy, dissipated energy, and damage indexes, was studied by Moustafa and Mahmoud (2014). Numerical examples of damage of fixed-base and base-isolated adjacent buildings with elastic-plastic force-deformation relation were considered. A probabilistic risk assessment for seismic pounding with efficient application to linear systems was performed by Tubaldi et al. (2012). To reduce the pounding probability of adjacent buildings, the proposed method was analyzed using viscous dampers and their capability was evaluated. The results obtained were validated against purely numerical simulation results.

The current research is focused on damage assessment in adjacent RC Moment Resisting Frames (MRFs) considering pounding effects under ground motion records. For this purpose, some illustrative benchmark structures, including 2- and 4-story as well as 4- and 8-story RC MRFs, were examined based on three damage indexes, i.e. Park and Ang index (Park and Ang 1985), modified Park and Ang damage index proposed by Kunnath et al. (1992) and Consenza et al. index (Cosenza et al. 1993).

\section{Nonlinear modeling of structures}

In this research, the 2-, 4- and 8-story RC MRFs, designed by Haselton and Deierlein (2005), were used. Each of the buildings was designed according to the IBC (2003), ASCE7-02 (2002), and ACI 318-02 (2002) (see Haselton and Deierlein 2005). In these models, three-dimensional effects and uncertainty in modeling were used (Deierlein and Haselton 2005). Also, deterioration modes that participated in the sideway 


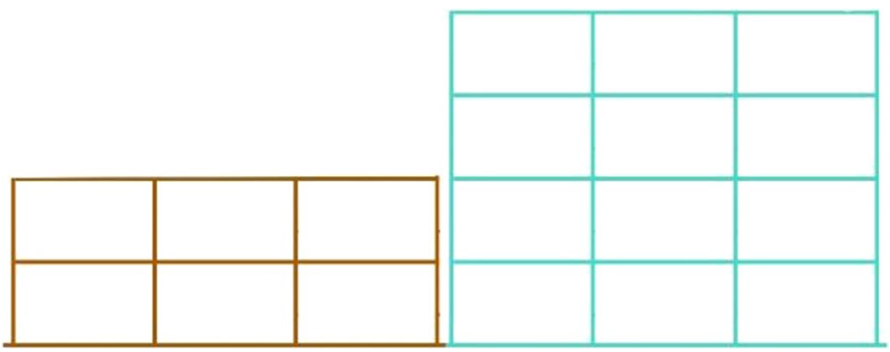

Fig. 1 Elevation views of the 2- and 4-story RC MRFs under consideration

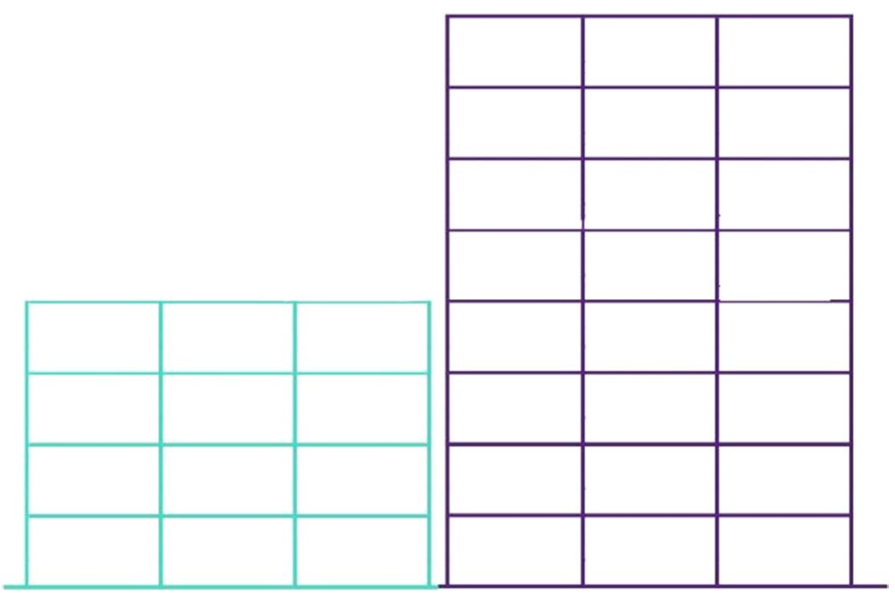

Fig. 2 Elevation views of the 4- and 8-story RC MRFs under consideration

collapse were considered using the element model developed by Ibarra and Krawinkler (2005) and Ibarra et al. (2005). In this regard, OpenSees software (McKenna et al. 2010) was used (Altoontash 2004). The elevation views of the 2-, 4- and 8-story RC MRFs, including geometry and dimensions, are presented in Fig. 1 and Fig. 2, respectively. The $P$-Delta effect was modeled using the concept of leaning column. The modified Ibarra-Krawinkler bilinear-hysteretic model, as a nonlinear rotational spring, was considered for deteriorating moment-rotation hysteresis (Lignos and Krawinkler 2010). Moreover, an elastic beam-column element in the middle and two zero-length elements located at both ends were also used in the model. In other words, in order to compute the damage indexes, the modified Ibarra-Medina-Krawinkler bilinear hysteretic model (IMK model) was implemented (see Ibarra et al. 2005) by applying a nonlinear rotational spring at both ends of each beam element and at both ends of each column element. Therefore, the relation between the moment and rotation $M-\theta$ for each hinge could be obtained, and finally, having the $M-\theta$ relation for each story, the damage indexes could be computed (Mohebi et al. 2019). 


\section{Modeling of pounding}

In this study, to model the pounding phenomenon, "the linear viscoelastic contact model (Kelvin-Voigt model) was employed using OpenSees software (McKenna et al. 2010). Pounding force in each story was obtained based on the following equation (Anagnostopoulos 1988):

$$
F(t)=K_{i m p} \delta(t)+C_{i m p} \dot{\delta}(t)
$$

where $K_{i m p}$ is the impact spring's stiffness coefficient, $\delta(\mathrm{t})$ is the interpenetration depth, $C_{i m p}$ is the impact damping coefficient, and $\dot{\delta}(\mathrm{t})$ is the relative velocity of pounding floors, respectively. The value of damping coefficient can be obtained as follows (Anagnostopoulos 1988):

$$
\begin{gathered}
C_{i m p}=2 \xi \sqrt{K_{i m p} \frac{m_{i} m_{j}}{m_{i}+m_{j}}} \\
\xi=\frac{-\ln (e)}{\sqrt{\pi^{2}+(\ln (e))^{2}}}
\end{gathered}
$$

where $\xi$ is the impact damping ratio, $e$ is the coefficient of restitution, and $m_{i}$ and $m_{j}$ are masses of two colliding structures. It was considered in the analysis that impact occurs at the story levels (slab-to-slab pounding). The coefficient of restitution accounts for the energy dissipation during impact due to such effects as plastic deformations, local cracking and friction, etc. (Goldsmith 1960). This parameter for concrete-to-concrete impact was assumed to be 0.65 (Mahmoud and Jankowski 2011; Anagnostopoulos and Karamaneas 2008). The impact stiffness coefficient depends mainly on the material characteristics of the colliding structures and the geometry at the vicinity of impact. Assuming that the contact geometry is taken into account with the use of the area of the overlapping region instead of the indentation depth, the impact stiffness coefficient should be directly related to the modulus of elasticity of the colliding structures. The equations proposed by Polycarpou et al. (2014) were used to determine the impact stiffness coefficient:

$$
\begin{gathered}
K_{\text {imp }}=\left[\frac{1-v_{1}^{2}}{E_{\text {Dynamic }, 1}}+\frac{1-v_{2}^{2}}{E_{\text {Dynamic }, 2}}\right]^{-1} \\
E_{\text {Dynamic }, i}=5.82\left(E_{\text {Static }, i}\right)^{0.63}, \text { in } G P a
\end{gathered}
$$

where $\nu_{i}$ is the Poisson's ratio, $E_{\text {Dynamic, } i}$, is the dynamic elastic modulus of normal strength concrete, $E_{\mathrm{Static}, i}$ is the static elastic modulus for structure $i$ that is calculated from the stress-strain diagram. The dynamic elastic modulus is used primarily to evaluate the soundness of concrete in durability tests; it is a more appropriate value when concrete is to be used in structures subjected to dynamic loading, i.e. impact or earthquake (Al-Amawee and Salman 2006). In this study, the static elastic modulus and the Poisson's ratio were assumed to be equal to $21 \mathrm{GPa}$ and 0.2 , respectively. In order to investigate the effect of separation distance on the seismic pounding of adjacent structures, separation distance equal to zero as well as equal to a minimum separation distance, $\delta_{M T}$, as calculated 
according to the ASCE seismic provision, was considered. Each pounding model was analyzed for two aforementioned separation distances and compared to the case when structures vibrate independently (without any adjacent structure).

\section{Incremental dynamic analysis}

Incremental Dynamic Analysis (IDA) is a technique to assess the seismic collapse capacities' of "structures utilizing a series of nonlinear dynamic analyses. Modern design provisions, such as FEMA P695 (2009), propose a set of 44 ground motions to be used in the analysis. This is done to take into account the record to record variability. Also, recent literature (see Baltzopoulos et al. 2019, for example) suggests that the number of records used can be kept in the 40 to 100 range and achieve $10 \%$ mean relative error. Therefore, in the current research, a set of 44 far-field ground motion records presented in FEMA P695 (2009) were used to perform IDAs (see Table 1). Figure 3a and b present the IDA curves (color curves) and their corresponding median (black curves) for the 4- and 8-story RC pounding structures, respectively, with the separation distance equal to zero.

\section{Implementation of damage indexes}

In order to present the damage level numerically, it is necessary to select a practical Damage Index $(D I)$. Using a proper $D I$, the local status of an element or the overall state of a structure after an earthquake loading can be determined. Application of DIs in damage detection of structures was studied by several researchers (Sharifi et al. 2012; Alhaddad et al. 2015; Nie et al. 2017; Pang et al. 2018; Huang et al. 2018). In this research work, three DIs proposed by Park and Ang (1985), Cosenza et al. (1993), and Kunnath et al. (1992) were selected to evaluate structural pounding damage in adjacent RC MRFs, which are considered as local DIs. As a matter of fact, a $D I$ is local when it refers to a single point, section, member, or structural part, whereas it is considered to be global when it defines the state of the entire structure (Hanganu et al. 2002). Then, a global DI is obtained through special combinations using weighted factors of local DIs. The weighting factor for any story can be related to the magnitude of its corresponding $D I$. On the other hand, a story with severe damage is a candidate for the bigger weight (Ghobarah et al. 1999). Weighted averaging methods were proposed by Park and Ang (1985) and Bracci et al. (1989) to integrate damage of single elements for each individual story. Park and Ang (1985) suggested a damage index which is based on deformation and energy concepts in structural elements, so as to achieve the damage level in each story and the overall structure based on Eq. (6) and Eq. (7), respectively:

$$
\begin{gathered}
D I_{\text {story }}=\sum_{i=1}^{n}\left(\lambda_{i, \text { component }} . D I_{i, \text { component }}\right) \\
D I_{\text {overall }}=\sum_{i=1}^{n}\left\{\left(\lambda_{i}\right)_{\text {story }}\left(D I_{i}\right)_{\text {story }}\right\}
\end{gathered}
$$

where 


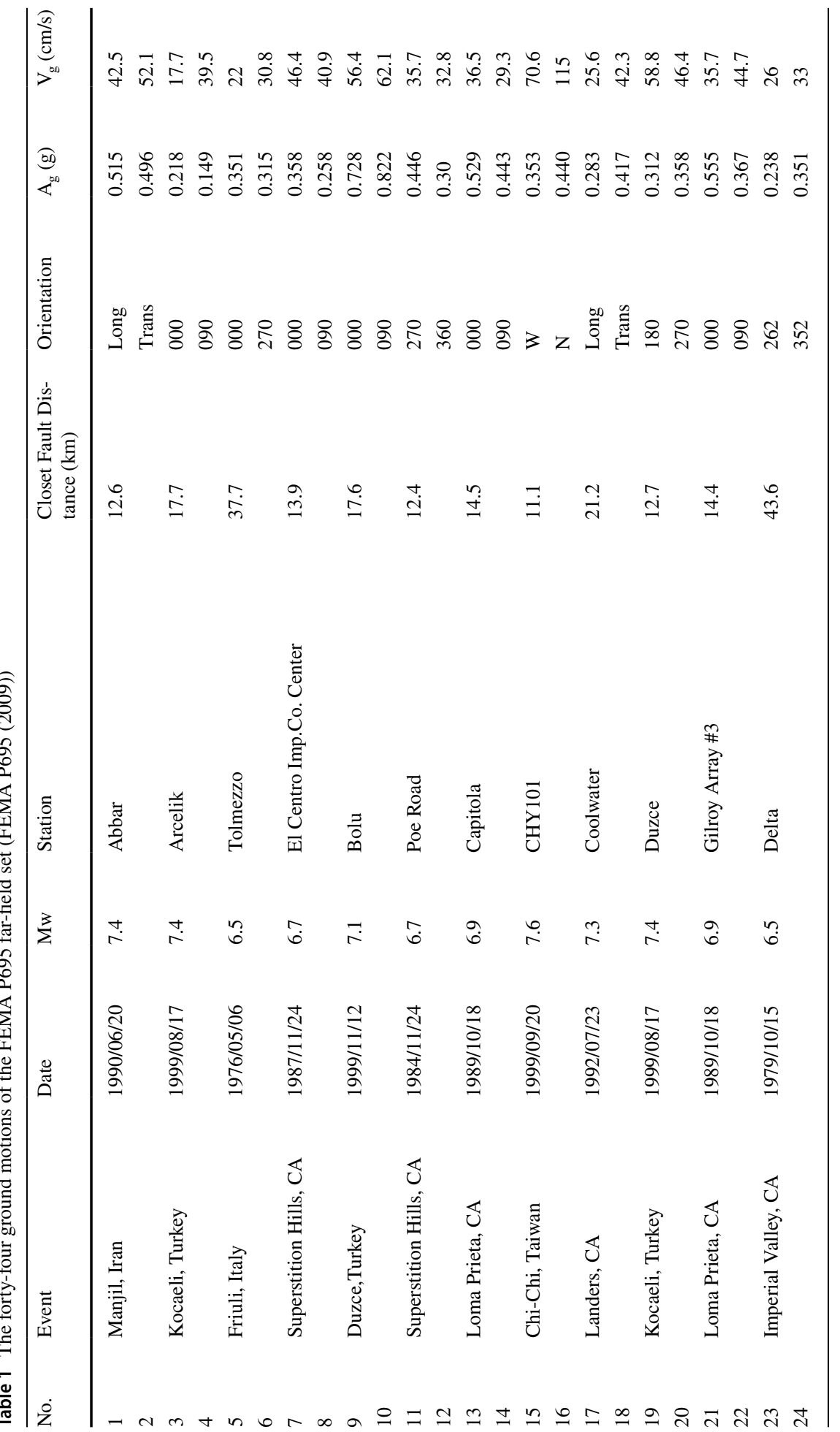




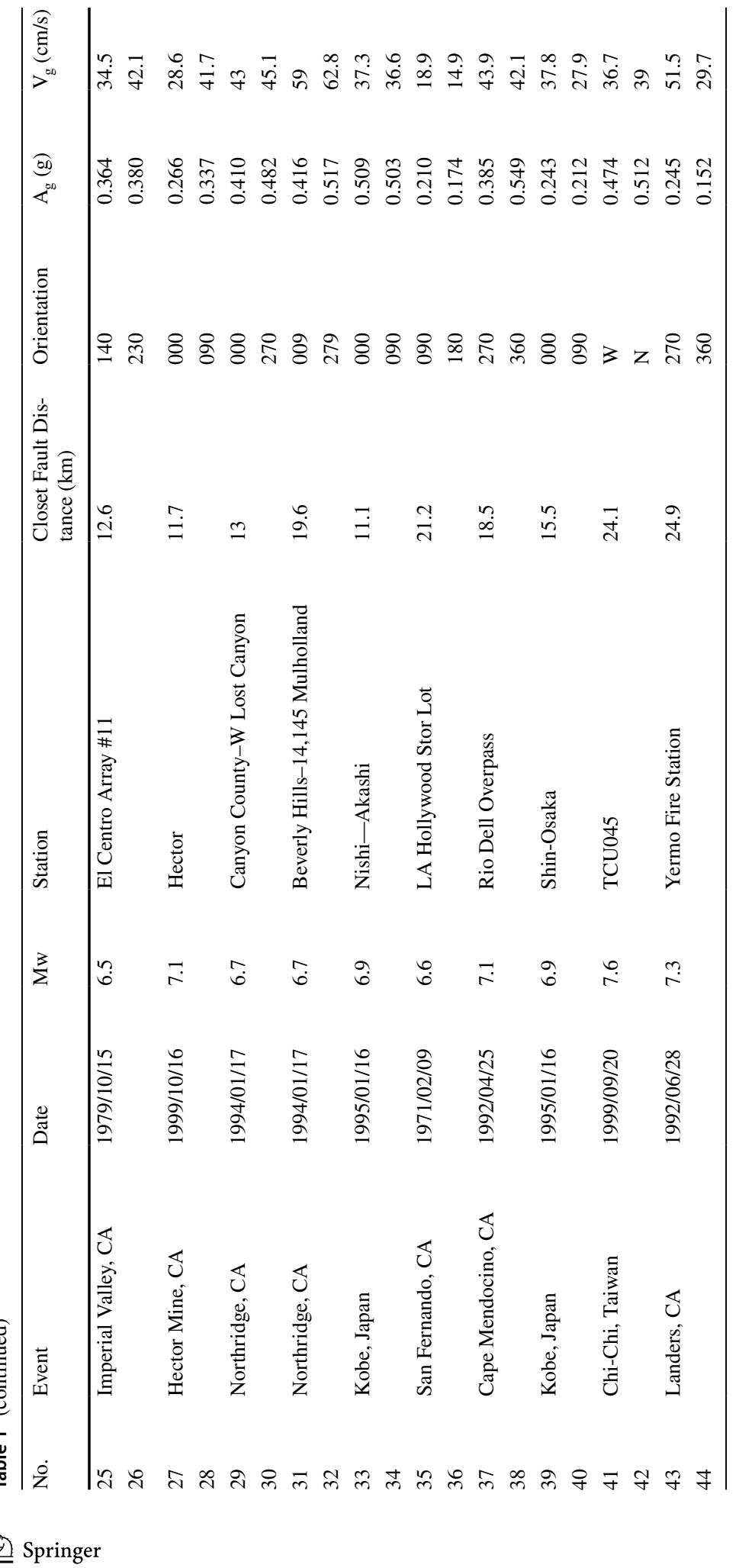



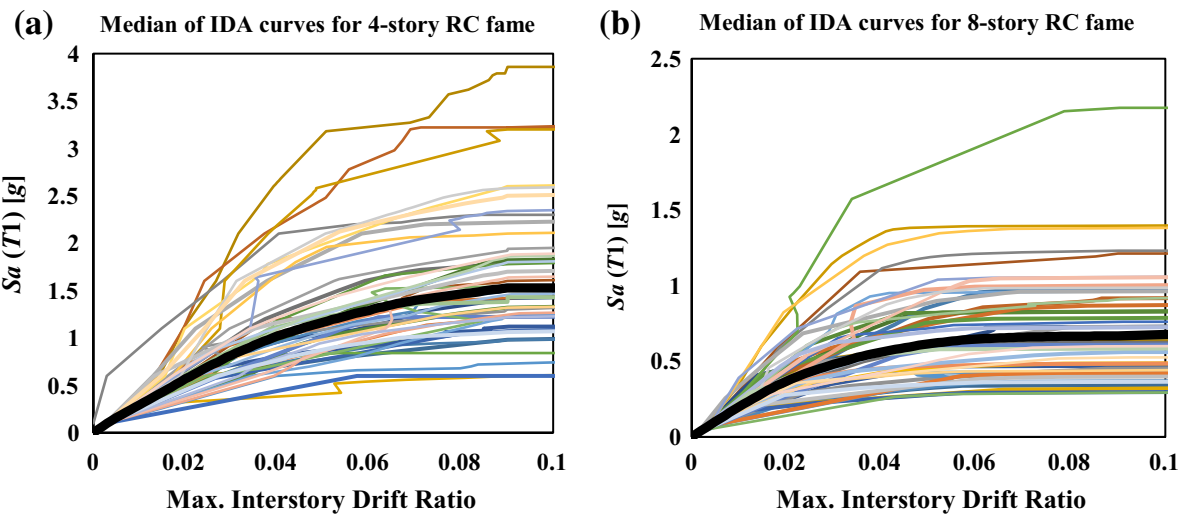

Fig. 3 IDA curves of the considered benchmark pounding structure with separation distance equal to 0 under 44 far-field ground motion records: a 4-story building, $\mathbf{b} 8$-story building

$$
\begin{aligned}
\left(\lambda_{i}\right)_{\text {component }} & =\left[\frac{E_{i}}{\sum_{k=1}^{n} E_{i}}\right]_{\text {component }} \\
\left(\lambda_{i}\right)_{\text {story }} & =\left[\frac{E_{i}}{\sum_{k=1}^{n} E_{i}}\right]_{\text {story }}
\end{aligned}
$$

It should be added that $E$ in Eq. (8) denotes the total energy dissipated by the element and $n$ is the number of elements of an individual story, whereas, $E$ in Eq. (9) represents the total energy absorbed by the story and $n$ is the number of stories.

The DI proposed by Cosenza et al. (1993) is presented by Eq. (10) as follows:

$$
D I=\frac{\mu-1}{\mu_{u, m o n}-1}
$$

where $\mu$ is the maximum ductility during the history of loading and $\mu_{u, \text { mon }}$ is the maximum allowable value of ductility, which is equal to $u_{u, m o n} / u_{y}$. It should be noted that $u_{u, \text { mon }}$ is the ultimate displacement under monotonic loading and $u_{y}$ is the yield displacement. For flexure-resisting components, $\mu, \mu_{u, m o n}, u_{u, m o n}$, and $u_{y}$ are replaced with $\mu_{\theta}, \mu_{\theta, m o n}, \theta_{u, m o n}$, and $\theta_{y}$, respectively. Moreover, $\mu_{\theta}$ is the rotation ductility during the loading history and $\mu_{\theta, \text { mon }}$ is the maximum allowable value of rotation ductility under monotonic loading, while $\theta_{u^{\prime} \text { mon }}$ and $\theta_{y}$ are the ultimate and the yield rotation, respectively. The damage index proposed by Park and Ang (1985) was extended and modified by Kunnath et al. (1992) using both deformation and hysteretic energy as follows:

$$
D I=\frac{\theta_{m}-\theta_{y}}{\theta_{u}-\theta_{y}}+\beta \frac{E_{h}}{M_{y} \theta_{u}}
$$

where $\theta_{m}$ is the maximum experienced rotation of an element in a system subjected to an earthquake, $\theta_{y}$ is the yield rotation under monotonic loading, $\theta_{u}$ is the ultimate rotation under monotonic loading, $E_{h}$ is the hysteretic energy dissipated by the element, $M_{y}$ is the 
yield moment and $\beta$ is a parameter calibrated in accordance with experiments to reflect the effect of repeated loading. In this paper, $\beta$ was assumed to be 0.15 for LS (Kunnath et al. 1992; Reinhorn et al. 2009).

The flowchart of the analysis is shown in Fig. 4.

Fig. 4 Analysis flowchart

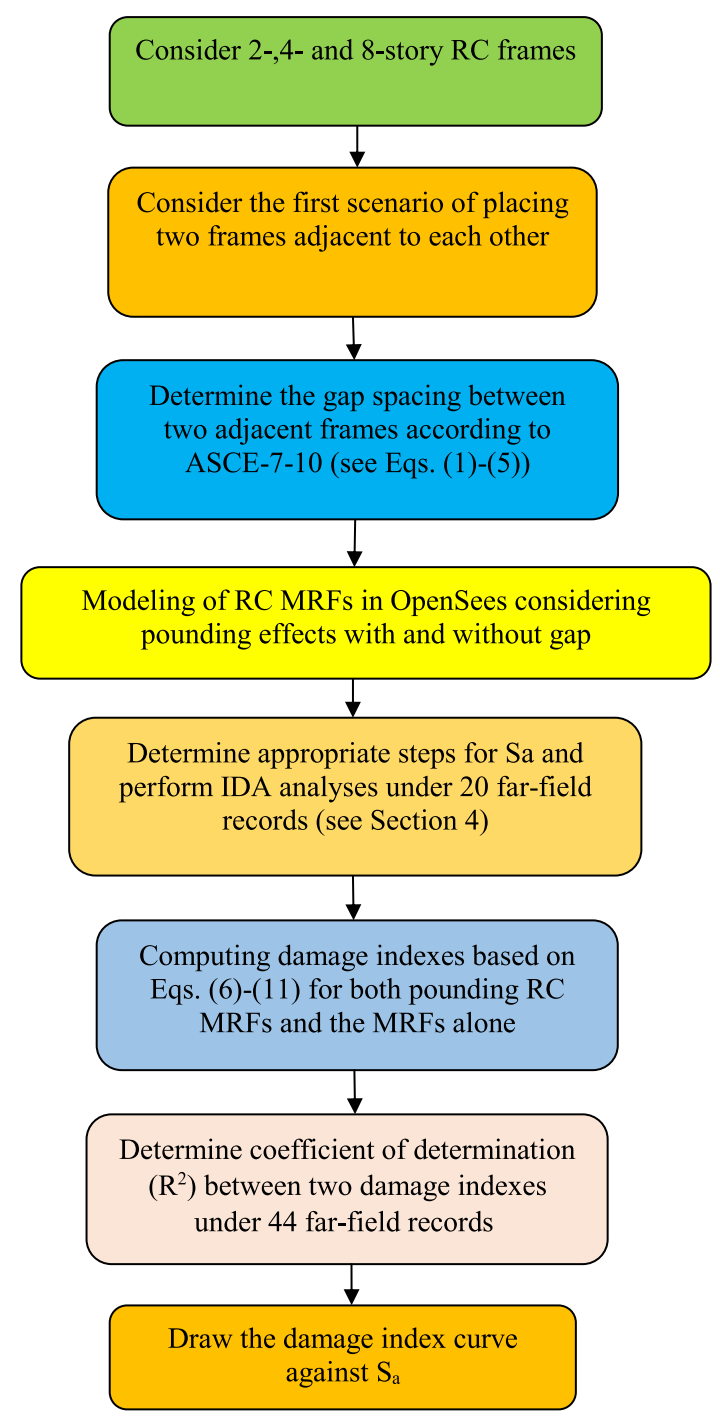




\section{Verification}

\subsection{Estimating the fundamental period of the MRFs}

In order to verify the fundamental period of the simulated models, the Numerical algorithms for Subspace State Space System Identification (N4SID) method, as candidate of system identification methods, along with stabilization diagram and Power Spectral Density (PSD), was employed to determine the modal parameters (i.e., natural frequency, damping ratio, and mode shapes). It is worth mentioning that in this method, acceleration responses recorded at the roof of the MRFs under specific ground motion records are selected as output signals, and also the ground motions can be used as input signals. More explanations about the stabilization diagram were presented by Yazdanpanah et al. (2020a, b). In addition, the mathematical relationship of the N4SID method can be found in the literature (Overschee and Moor 1994; Kim and Lynch 2012). As it can be observed in Fig. 5, the fundamental period of the 4-story RC MRF could be estimated as $T_{1}=1 / f_{1}=1 / 0.895=1.1173(\mathrm{sec})$, which accurately matches with the fundamental period obtained by OpenSees, i.e. $T_{1}=1.1002489$ (sec). Also, Fig. 6 indicates that the first identified period of the 8-story RC MRF is $T_{1}=1 / f_{1}=1 / 0.620=1.6129$ (sec) slightly less than the fundamental period obtained by OpenSees, i.e. $T_{1}=1.681477(\mathrm{sec})$.

\subsection{Linear viscoelastic contact element}

To justify the impact force between two adjacent frames using the linear viscoelastic contact element, a numerical model was simulated in OpenSees. All the frame models (with and without considering the pounding phenomenon) were studied under the El Centro earthquake using the shaking table (see Fig. 7). Comparison between numerical and experimental results (Khatiwada et al. 2013) indicated that the maximum
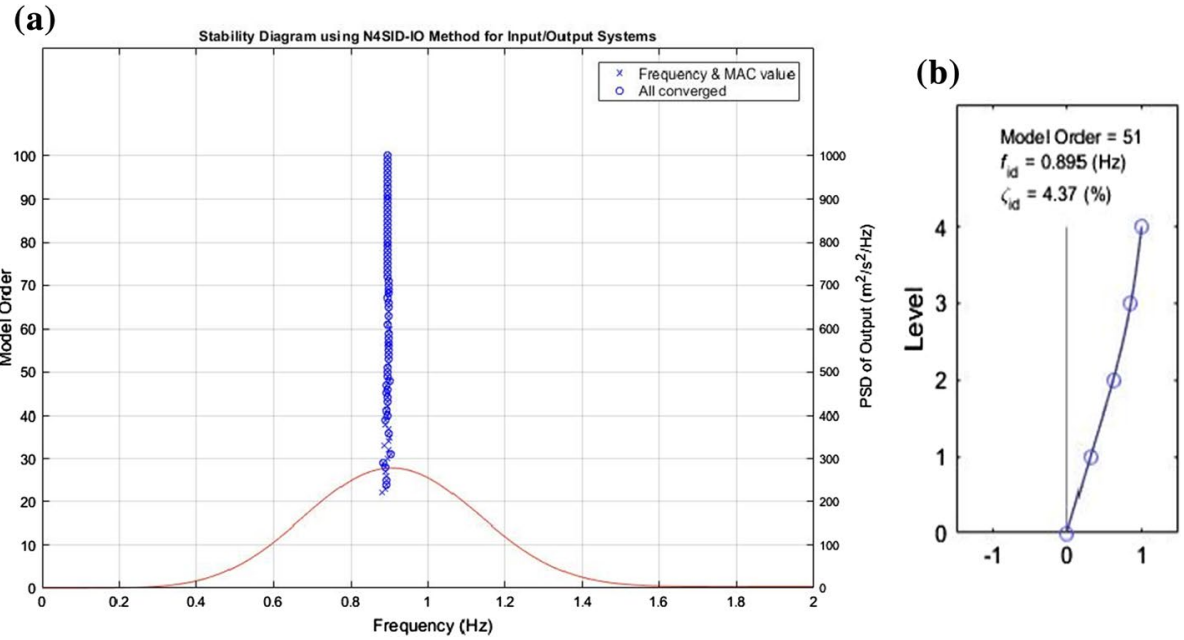

Fig. 5 Stabilization diagram of the 4-story RC MRF using the N4SID method. a stabilization diagram, b identified modal parameters 


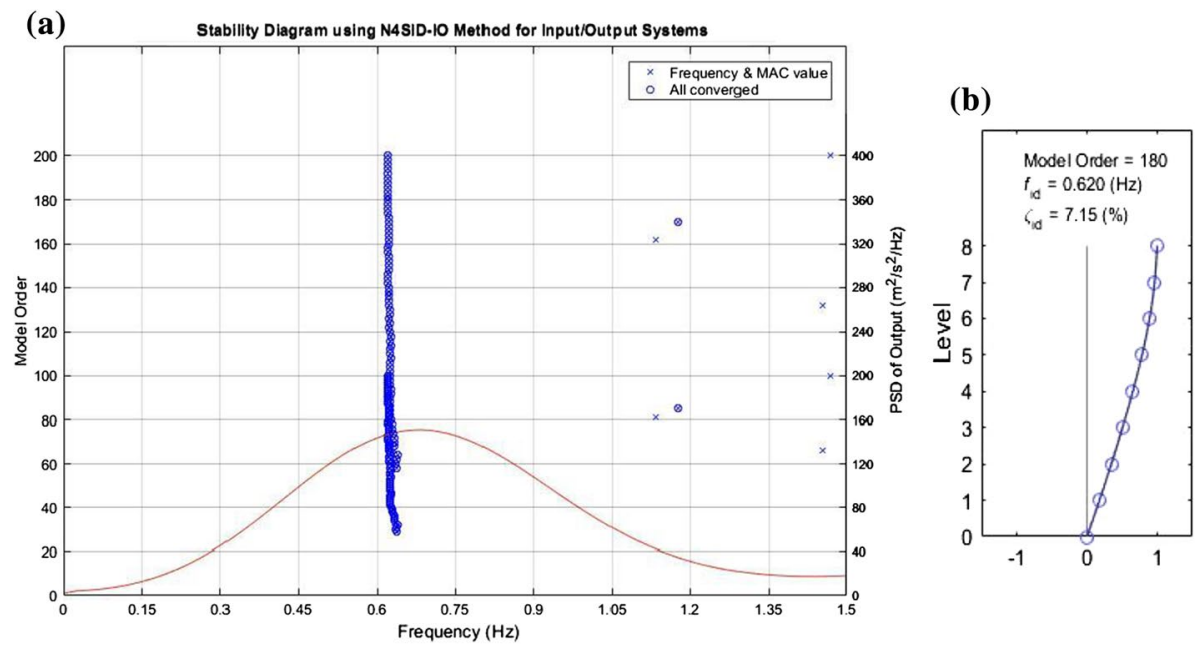

Fig. 6 The stabilization diagram of the 8-story RC MRF using the N4SID method. a stabilization diagram, b identified modal parameters

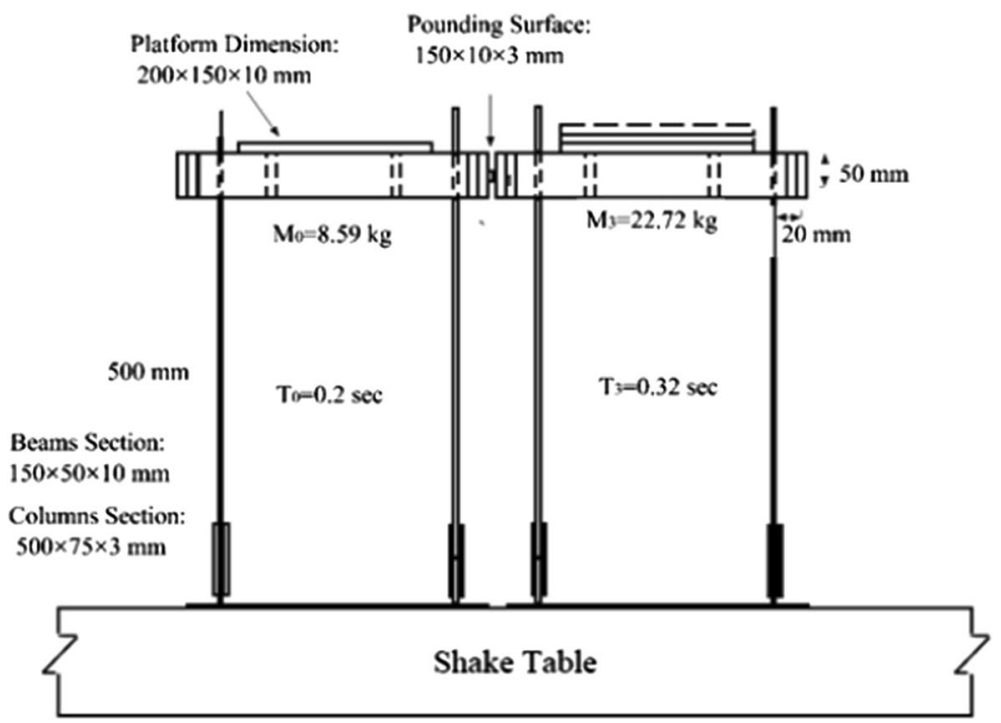

Fig. 7 Schematic view of the experimental setup (Khatiwada et al. 2013) (CC-BY license, New Zealand Society for Earthquake Engineering)

amplification factor $\left(\mu_{\max } / u_{\max }\right)$ for the numerical model was +1.23 and -1.35 for positive and negative directions, respectively; while these values in the experimental model (Khatiwada et al. 2013) were +1.26 and -1.3 for positive and negative directions, respectively. It is worth mentioning that $\mu_{\max }$ and $u_{\max }$ are the maximum deformations of the reference frame with and without pounding effects, respectively. Therefore, the linear viscoelastic contact element leads to good agreement between numerical and 
experimental results and it can be successfully used to study pounding between two adjacent frames.

\section{Results}

\subsection{Damage Indexes in 2- and 4-story RC MRFs considering pounding effects}

Figure 8a, b show the three damage indexes (Park and Ang, modified Park and Ang proposed by Kunnath et al. 1992 and Cosenza et al.) for 2-story RC MRFs considering pounding effects with a minimum separation distance, $\delta_{M T}$, as a function of the spectrum acceleration $\left(S_{a}\right)$, subjected to ground motions no. 13 and 17 of Table 1, respectively. It should be noted that these DIs denote the global damage of the frames. As it can be observed from the figures, all three damage indexes approximately lead to the same results. Based on these results, it can be concluded that the 2-story RC MRF is damaged under ground motions no. 13 and 17 within the range of $S_{a}: 1.1(\mathrm{~g})$ to $S_{a}: 1.6(\mathrm{~g})$ and $S_{a}: 1.6(\mathrm{~g})$ to $S_{a}: 2.1$ (g) for the first time. On the other hand, the damage indexes have high values in these steps. It is worth mentioning that the differences between these ranges for the modified Park and Ang damage index under records no. 13 and 17 are larger by about 0.032 and 0.018 , respectively, than for the Cosenza et al. damage index. Moreover, the MRF is collapsed under ground motions no. 13 and 17 when $S_{a}: 2.05(\mathrm{~g})$ to $S_{a}: 2.1(\mathrm{~g})$ and $S_{a}: 3.2(\mathrm{~g})$ to $S_{a}: 3.25(\mathrm{~g})$ (see big changes for these steps).

Figure 9a, b show correlations between the Kunnath et al. damage index and that of Cosenza et al. with minimum separation distance subjected to 44 far-field ground motions that correspond to all beams and columns of the 2-story RC MRF and 4-story RC MRF, respectively. As can be observed from the figures, the coefficients of determination $\left(R^{2}\right)$ are very strong and the damage indexes are well correlated.

Based on Fig. 10, it can be concluded that the 4-story RC pounding MRF with minimum separation distance is damaged under ground motions no. 13 and 17 within the range of $S_{a}: 0.6(\mathrm{~g})$ to $S_{a}: 1.1(\mathrm{~g})$ for the first time. On the other hand, the damage indexes have high values in this step. Also, the coefficient of determination for the aforementioned damage indexes (presented in Fig. 9b) indicates the high correlation between them. It is worth

(a)

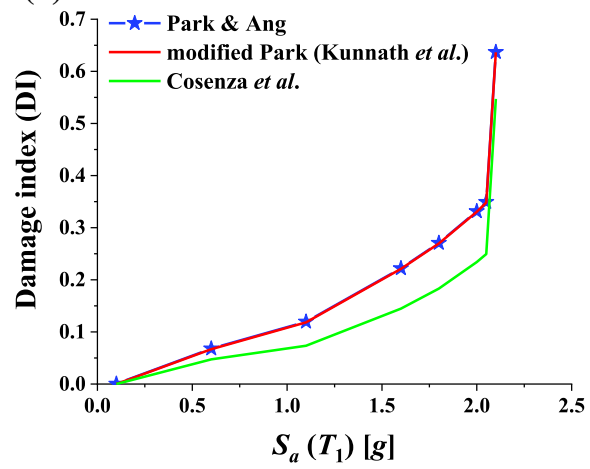

(b)

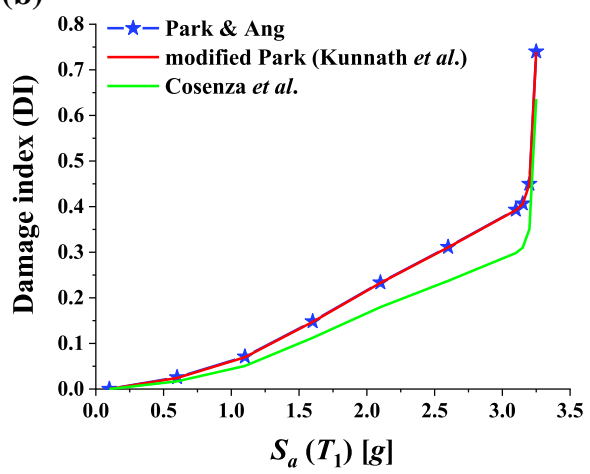

Fig. 8 Comparison of various damage indexes for the 2-story RC MRF considering pounding effect with minimum separation distance subjected to, a ground motion no. 13, b ground motion no. 17 
(a)

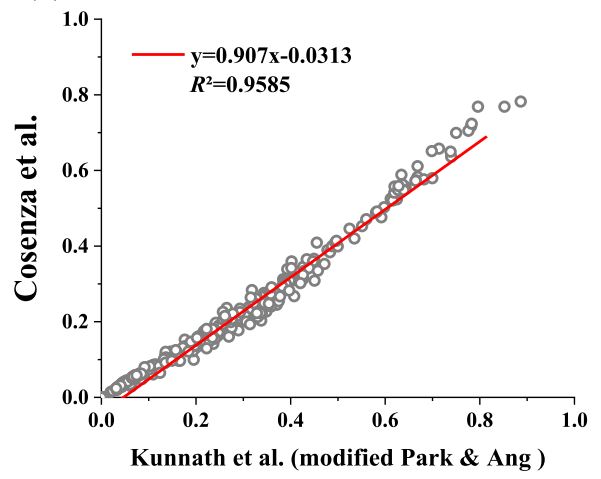

(b)

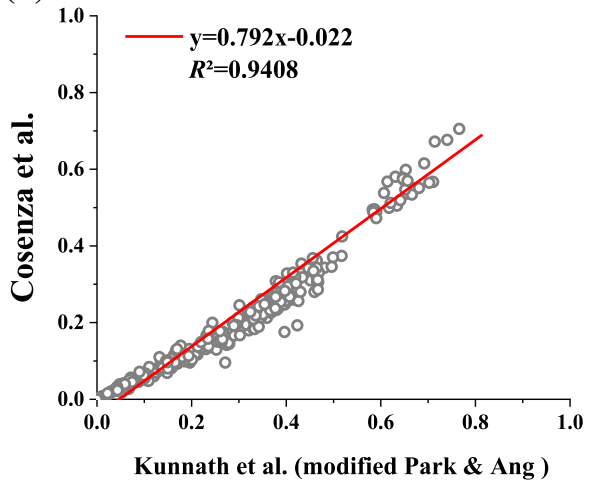

Fig. 9 Correlation between the Kunnath et al. damage index and that of Cosenza et al. with minimum separation distance subjected to 44 far-field ground motions that correspond to all beams and columns of the: a 2-story RC MRF, b 4-story RC MRF

(a)

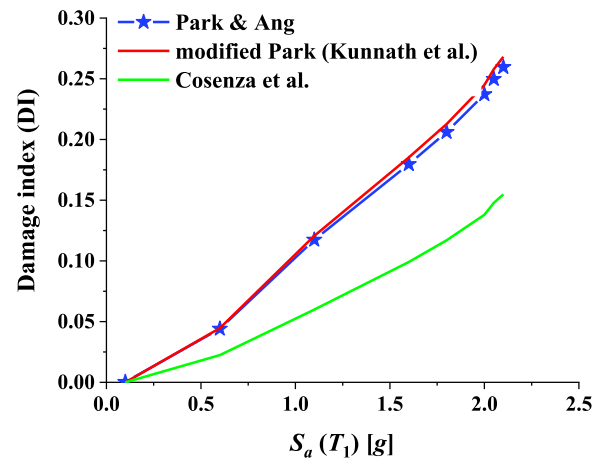

(b)

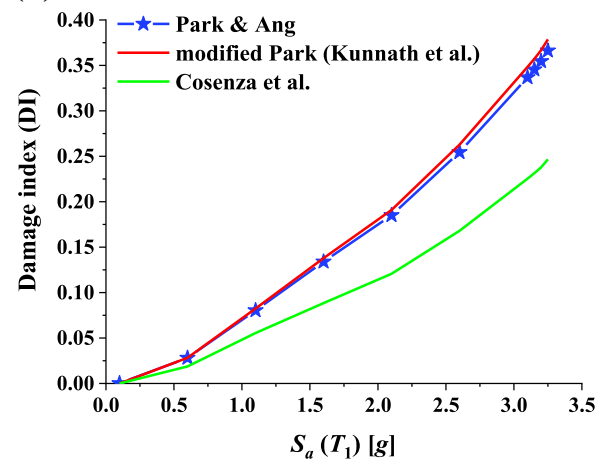

Fig. 10 Comparison of various damage indexes for the 4-story RC MRF considering pounding effect with minimum separation distance subjected to, a ground motion no. 13, b ground motion no. 17

mentioning that, the differences between this range for modified Park and Ang damage index under records no. 13 and 17 are larger by about 0.038 and 0.017 , respectively than for the Cosenza et al. damage index.

Figure $11 \mathrm{a}, \mathrm{b}$ present a comparison of various damage indexes for the 2-story RC MRF considering pounding effect without minimum separation distance subjected to ground motion no. 13 and 17, respectively. The results show that the 2-story RC MRF is damaged under ground motions no. 13 and 17 within the range of $S_{a}: 0.6(\mathrm{~g})$ to $S_{a}: 1.1(\mathrm{~g})$ and $S_{a}: 1.1$ (g) to $S_{a}: 1.6(\mathrm{~g})$ for the first time. On the other hand, the damage indexes have high values in these steps. The differences between these ranges for the modified Park \& Ang damage index under records no. 13 and 17 are larger by about 0.029 and 0.014 , respectively, than for the Cosenza et al. damage index. Moreover, the MRF is collapsed under ground motions no. 13 and 17 when $S_{a}: 2.1(\mathrm{~g})$ to $S_{a}: 2.15(\mathrm{~g})$ and $S_{a}: 3.05(\mathrm{~g})$ to $S_{a}: 3.1(\mathrm{~g})$ (see the big changes in these steps).

Figure 12a, b show correlations between the Kunnath et al. damage index and that of Cosenza et al. without minimum separation distance subjected to 44 far-field ground 
(a)

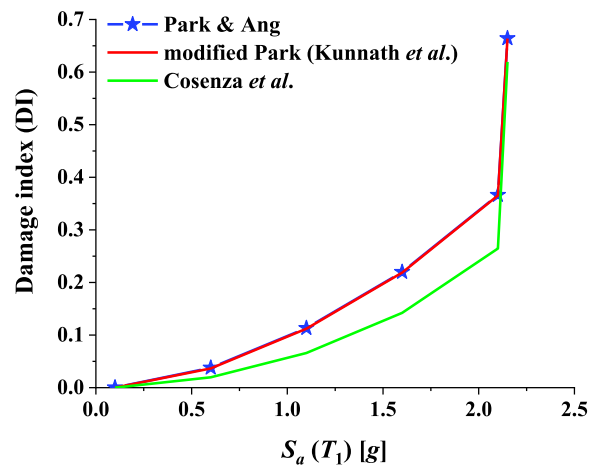

(b)

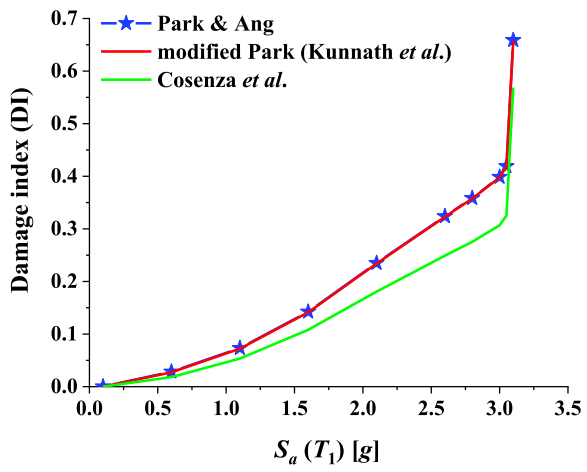

Fig. 11 Comparison of various damage indexes for the 2-story RC MRF considering pounding effect without minimum separation distance subjected to, a ground motion no. 13, b ground motion no. 17

(a)

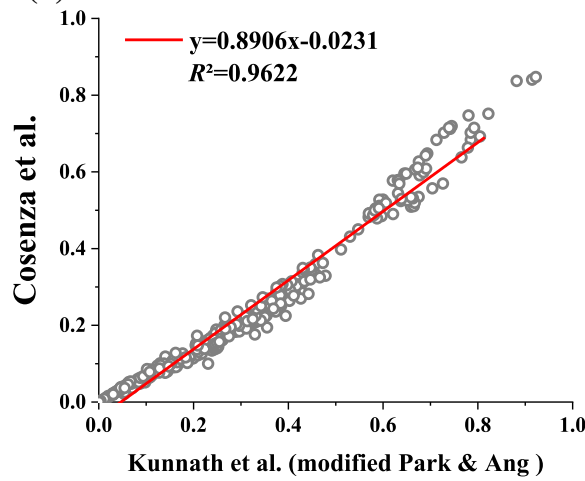

(b)

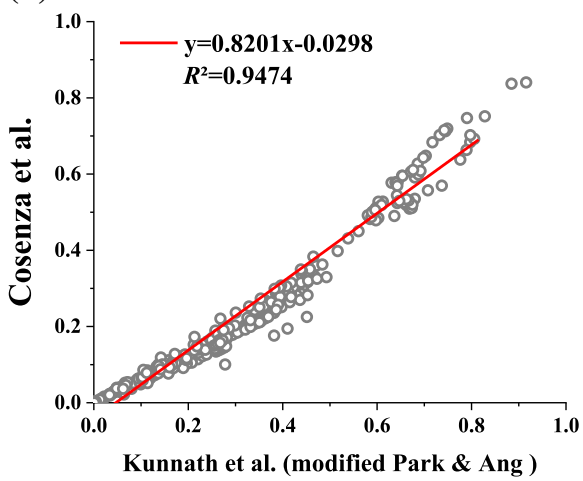

Fig. 12 Correlation between the Kunnath et al. damage index and that of Cosenza et al. without minimum separation distance subjected to 44 far-field ground motions that correspond to all beams and columns of the: a 2-story RC MRF, b 4-story RC MRF

motions that correspond to all beams and columns of the 2-story RC MRF and 4-story RC MRF, respectively. As it can be observed, the coefficients of determination are very strong and the damage indexes are well correlated.

Based on Fig. 13, it can be concluded that the 4-story RC pounding MRF without minimum separation distance is damaged under ground motions no. 13 and 17 within the range of $S_{a}: 0.1(\mathrm{~g})$ to $S_{a}: 0.6(\mathrm{~g})$ and $S_{a}: 0.6(\mathrm{~g})$ to $S_{a}: 1.1(\mathrm{~g})$ for the first time. On the other hand, the damage indexes have high values in this step. Consequently, the differences between these ranges for the modified Park \& Ang damage index under records no. 13 and 17 are larger by about 0.031 and 0.015 , respectively, than for the Cosenza et al. damage index.

According to the aforementioned results, the modified Park \& Ang damage index, due to larger differences for different damage states $\left(S_{a}\left(T_{1}\right)\right)$, is more sensitive to seismic damages. Also, the coefficient of determination for the aforementioned damage index is presented in Fig. 12b, which indicates on high correlation. It is worth mentioning that, during pounding between 2- and 4-story RC MRFs, the 4-story has lower values of damage indexes. It means that the 4-story is damaged at lower seismic intensities. In addition, as it 
(a)

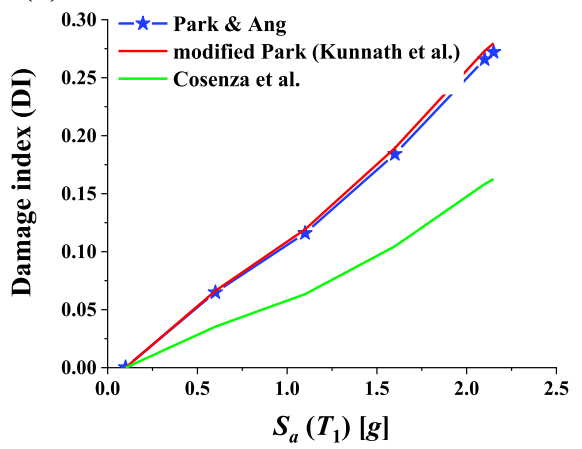

(b)

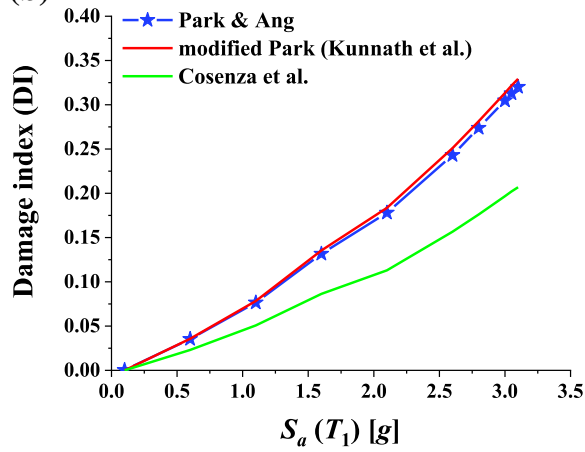

Fig. 13 Comparison of various damage indexes for the 4-story RC MRF considering pounding effect without minimum separation distance subjected to: a ground motion no. 13, b ground motion no. 17

(a)

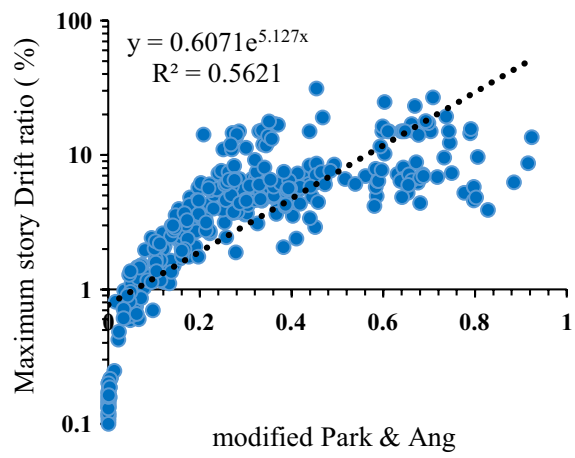

(b)

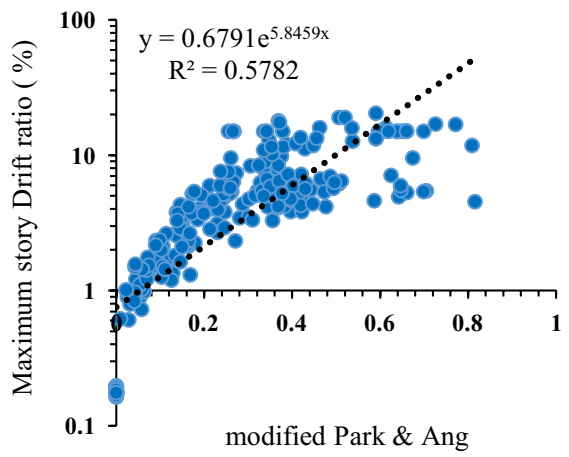

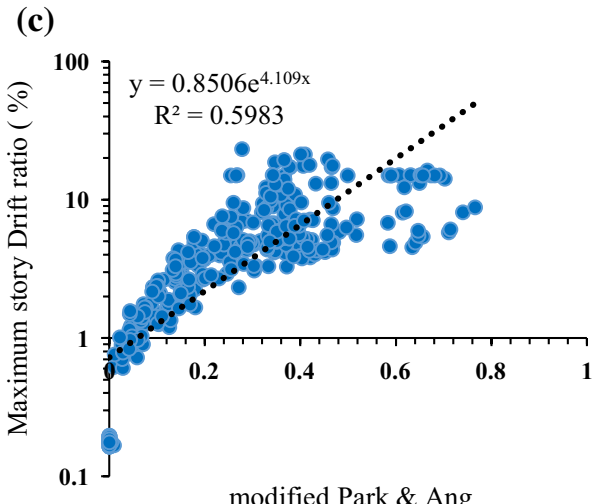

modified Park \& Ang

Fig. 14 Comparison of the coefficient of determination for the 4-story RC MRF subjected to 44 far-field ground motions considering pounding effects: a without minimum separation distance $\mathbf{b}$ with $75 \%$ of minimum separation distance, $\mathbf{c}$ with $100 \%$ of minimum separation distance 


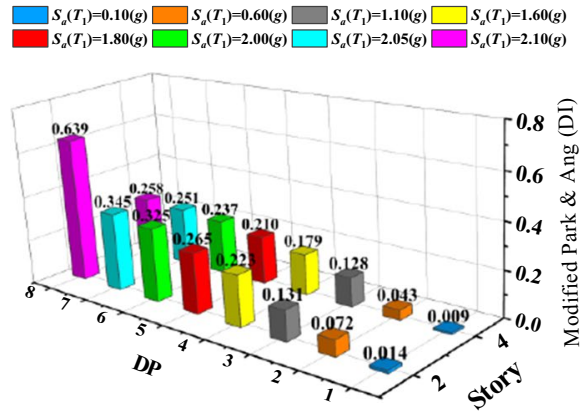

(a)

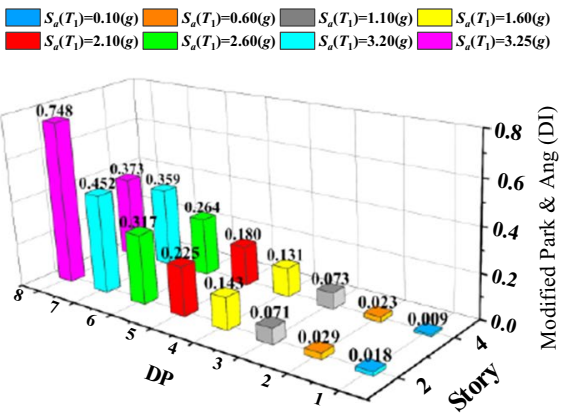

(b)

Fig. 15 Comparison of modified Park \& Ang damage index for pounding between 2- and 4-story RC MRFs with minimum separation distance subjected to: a ground motion no. 13, b ground motion no. 17

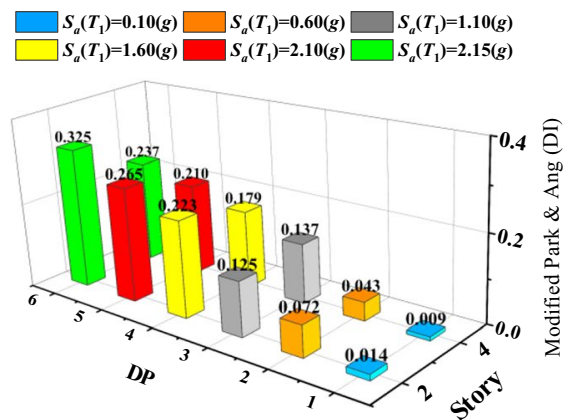

(a)

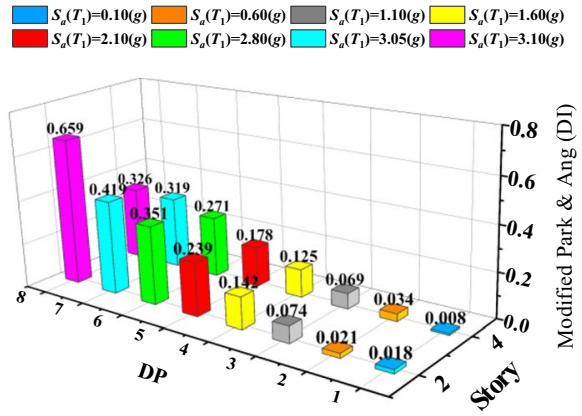

(b)

Fig. 16 Comparison of modified Park \& Ang damage index for pounding between 2- and 4-story RC MRFs without minimum separation distance subjected to: a ground motion no. 13, b ground motion no. 17

can be observed from Fig. 14a, b, and c, considering a minimum separation distance, $\delta_{M T}$, between two adjacent MRFs (2- and 4-story) leads to an increase in $R^{2}$ value for the maximum story drift ratio versus the modified Park \& Ang damage index. On the other hand, considering $75 \%$ and $100 \%$ of $\delta_{M T}$ improves the $R^{2}$ value up to $2.86 \%$ and $6.44 \%$, respectively and correlation between these two parameters increases.

Furthermore, comparing the damage indexes for 2- and 4-story RC MRFs considering pounding effect with minimum separation distance (Figs. 8a vs. 10a, 8b vs. 10b) and without minimum separation distance (Figs. 11a vs. 13a, 11b vs. 13b) under the same earthquakes and the same value of $S_{a}$, it can be seen that the damage indexes of the shorter structure are larger than values for the taller structure. In addition, Fig. 15 shows a comparison of modified Park \& Ang damage index for pounding between 2- and 4-story RC MRFs with minimum separation distance subjected to ground motion no. 13 and 17 with the same value of $S_{a}$. Moreover, a comparison of modified Park \& Ang damage index for pounding between 2- and 4-story RC MRFs without minimum separation distance subjected to ground motion no. 13 and 17 with the same value of $S_{a}$. is presented in Fig. 17. The results shown in both figures (Figs. 16 and 17) confirm that the shorter structure with smaller value of natural period will suffer more extensive damages due to structural pounding. 
(a)

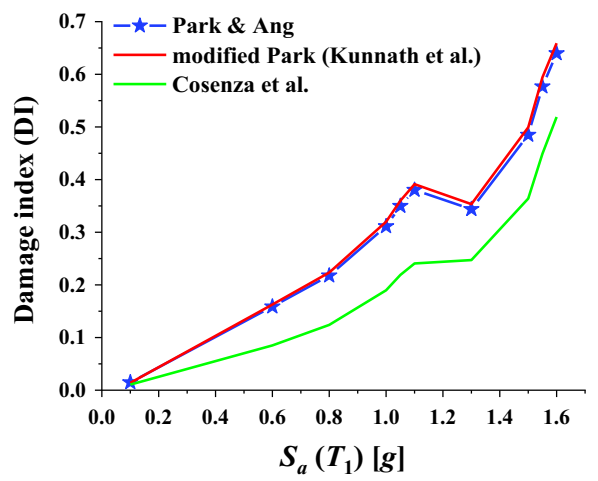

(b)

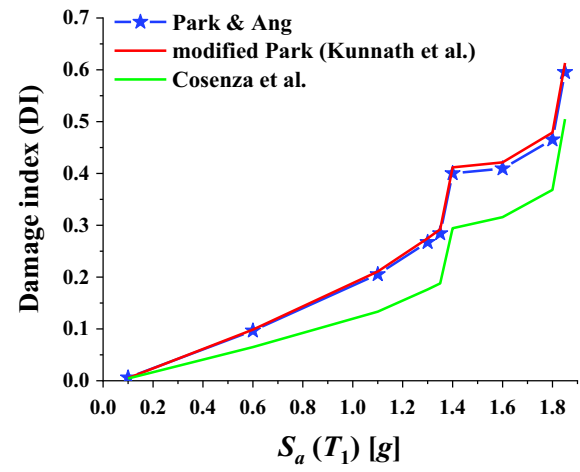

Fig. 17 Comparison of various damage indexes for the 4-story RC MRF considering pounding effect with minimum separation distance subjected to a ground motion no. 13, b ground motion no. 17

\subsection{Damage indexes in 4- and 8-story RC MRFs considering pounding effects}

Figure 17a and $\mathrm{b}$ show the three damage indexes (Park \& Ang, modified Park \& Ang proposed by Kunnath et al. (1992) and Cosenza et al.) for 4-story RC MRFs considering pounding effects with a minimum separation distance as a function of the spectrum acceleration $\left(S_{a}\right)$, subjected to ground motions no. 13 and 17 of Table 1, respectively. It should be noted that these DIs denote global damage of the frames. As it can be observed from the figures, all three damage indexes lead approximately to the same results. Based on these results, it can be concluded that the 4-story RC MRF is damaged under ground motions no. 13 and 17 within the range of $S_{a}: 0.1(\mathrm{~g})$ to $S_{a}: 0.6(\mathrm{~g})$ and $S_{a}: 0.1(\mathrm{~g})$ to $S_{a}: 0.6(\mathrm{~g})$ for the first time. On the other hand, the damage indexes have high values in these steps. It is worth mentioning that, the differences between this range for the modified Park \& Ang damage index under records no. 13 and 17 are larger by about 0.074 and 0.033 , respectively, than for the Cosenza et al. damage index. Moreover, the MRF is collapsed under ground motions no. 13 and 17 when $S_{a}: 1.3$ (g) to $S_{a}: 1.5(\mathrm{~g})$ and $S_{a}: 1.35(\mathrm{~g})$ to $S_{a}: 1.40(\mathrm{~g})$ (see the big changes in these steps).

Figure $18 \mathrm{a}$ and $\mathrm{b}$ show correlations between the Kunnath et al. damage index and that of Cosenza et al. with minimum separation distance subjected to 44 far-field ground motions that correspond to all beams and columns of the 4-story RC MRF and 8-story RC MRF, respectively. As it can be observed, the coefficients of determination are very strong and the damage indexes are well correlated.

Based on Fig. 19, it can be concluded that the 8-story RC pounding MRF with a minimum separation distance is damaged under ground motions no. 13 and 17 within the range of $S_{a}: 0.1(\mathrm{~g})$ to $S_{a}: 0.6$ (g) for the first time. On the other hand, the damage indexes have high values in this step. The differences between this range for the modified Park \& Ang damage index under records no. 13 and 17 are larger by about 0.099 and 0.117 , respectively, than for the Cosenza et al. damage index. Moreover, the MRF is collapsed under ground motions no. 13 and 17 when $S_{a}: 0.7(\mathrm{~g})$ to $S_{a}: 0.75(\mathrm{~g})$ and $S_{a}: 0.6(\mathrm{~g})$ to $S_{a}: 0.65(\mathrm{~g})$ (see the big changes in these steps). Also, the coefficients of determination for the aforementioned damage index are presented in Fig. 23c, which indicates on high correlation. 
(a)

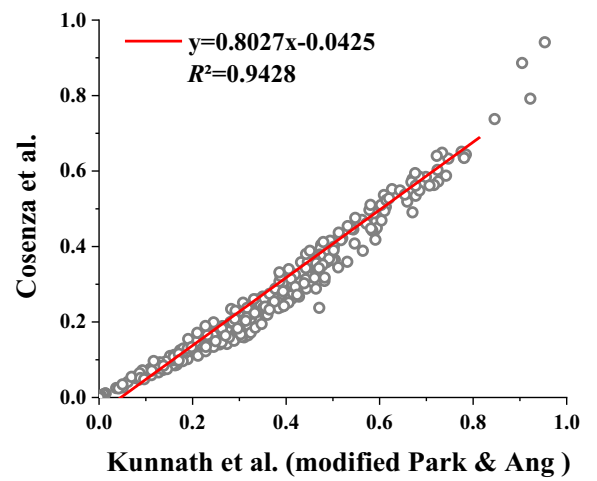

(b)

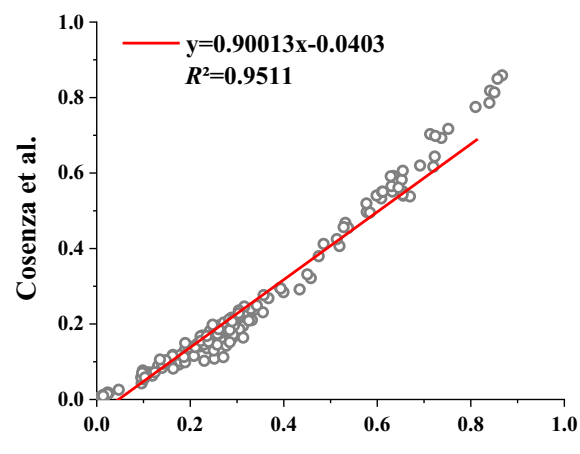

Kunnath et al. (modified Park \& Ang )

Fig. 18 Correlation between the Kunnath et al. damage index and that of Cosenza et al. with minimum separation distance subjected to 44 far-field ground motions that correspond to all beams and columns of the: a 4-story RC MRF, b 8-story RC MRF

(a)

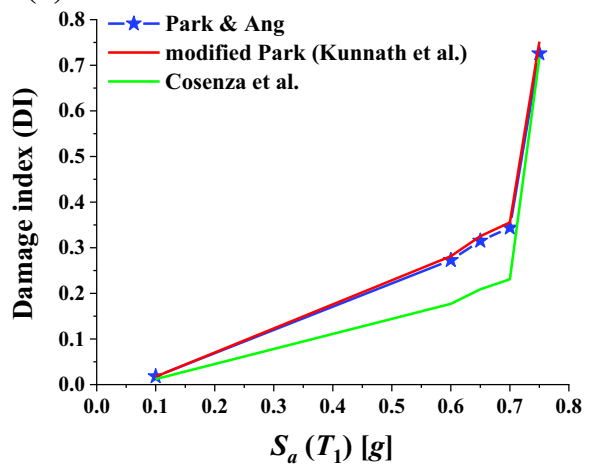

(b)

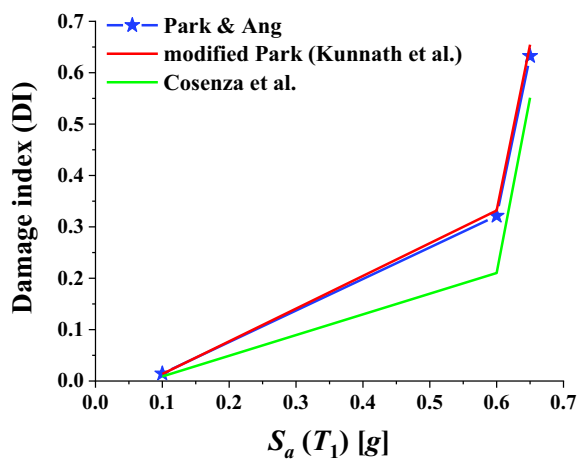

Fig. 19 Comparison of various damage indexes for the 8-story RC MRF considering pounding effect with minimum separation distance subjected to, a ground motion no. 13, b ground motion no. 17

Figure $20 \mathrm{a}$ and $\mathrm{b}$ present a comparison of various damage indexes for the 4-story RC MRF considering pounding effect without a minimum separation distance subjected to ground motion no. 13 and 17, respectively. The results show that the 4-story RC MRF is damaged under ground motions no. 13 and 17 within the range of $S_{a}: 0.1(\mathrm{~g})$ to $S_{a}: 0.6(\mathrm{~g})$ and $S_{a}: 0.1(\mathrm{~g})$ to $S_{a}: 0.6(\mathrm{~g})$ for the first time. On the other hand, the damage indexes have high values in these steps. It is worth mentioning that, the differences between this range for the modified Park \& Ang damage index under records no. 13 and 17 are larger by about 0.077 and 0.031 , respectively, than for the Cosenza et al. damage index. It is worth noting that pounding between two adjacent MRFs leads to a decrease in the intensity of an earthquake. On the other hand, the MRF is damaged under lower seismic intensities than the state of pounding with minimum separation distance. Therefore, considering a minimum separation distance based on ASCE seismic criteria is necessary.

Figure $21 \mathrm{a}$ and $\mathrm{b}$ show correlations between the Kunnath et al. damage index and that of Cosenza et al. without a minimum separation distance subjected to 44 far-field ground 
(a)

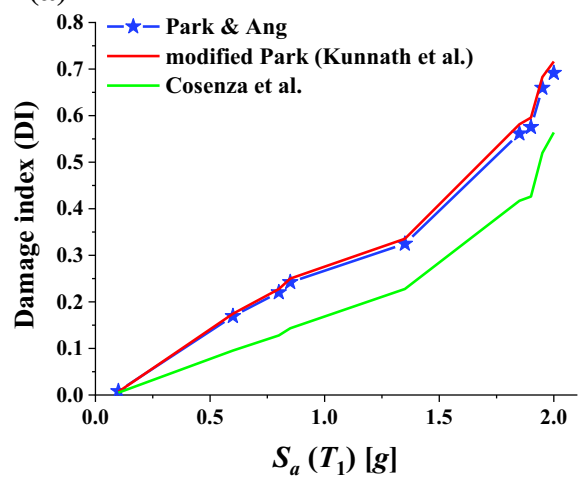

(b)

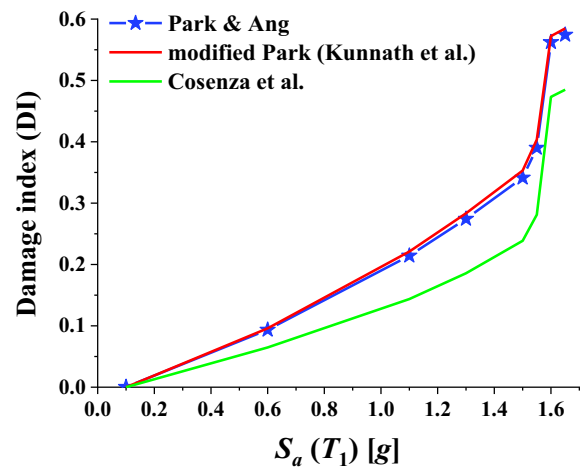

Fig. 20 Comparison of various damage indexes for the 4-story RC MRF considering pounding effect without minimum separation distance subjected to: a ground motion no. 13, b ground motion no. 17

(a)

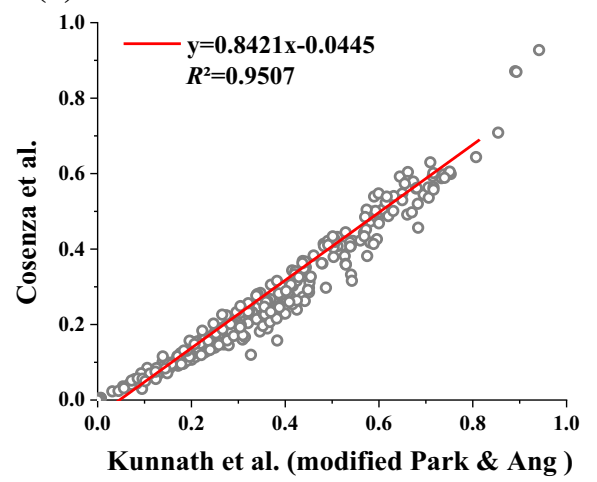

(b)

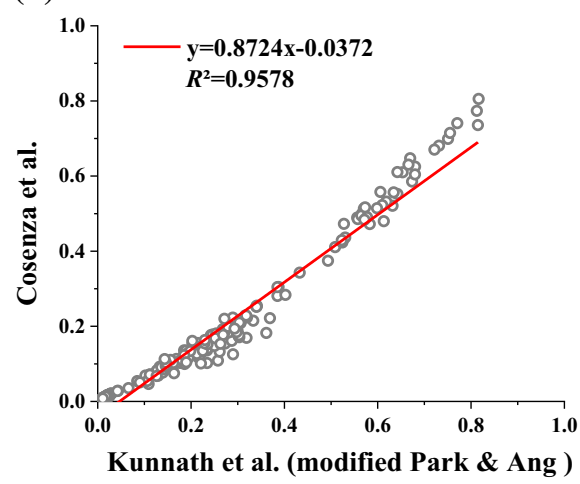

Fig. 21 Correlation between the Kunnath et al. damage index and that of Cosenza et al. without minimum separation distance subjected to 44 far-field ground motions that correspond to all beams and columns of the: a 4-story RC MRF, b 8-story RC MRF

motions that correspond to all beams and columns of the 8-story RC MRF and 4-story RC MRF, respectively. As it can be observed, the coefficients of determination are very strong and the damage indexes are well correlated.

Based on Fig. 22, it can be concluded that the 8-story RC pounding MRF without a minimum separation distance is damaged under ground motions no. 13 and 17 within the range of $S_{a}: 0.1(\mathrm{~g})$ to $S_{a}: 0.6(\mathrm{~g})$ for the first time. On the other hand, the damage indexes have high values in this step. It is worth mentioning that, the differences between this range for the modified Park \& Ang damage index under records no. 13 and 17 are larger by about 0.026 and 0.028 , respectively, than for the Cosenza et al. damage index Fig. 23. Also, the coefficients of determination for the aforementioned damage index are presented in Fig. 24d, which indicates on high correlation. Like 4-story MRF considering pounding effect without a minimum separation distance, pounding between two adjacent MRFs leads to the decrease in the intensity of an earthquake. On the other 
(a)

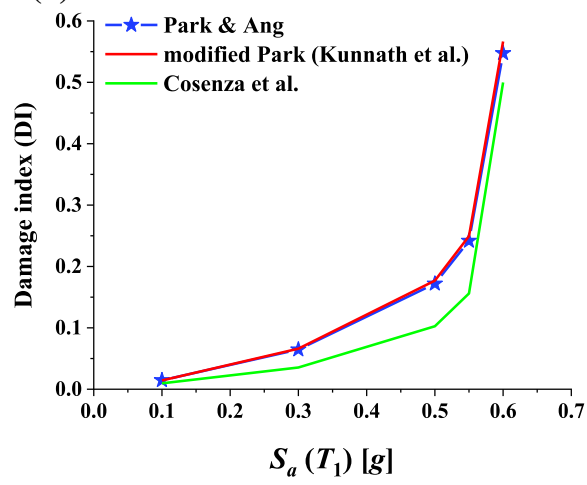

(b)

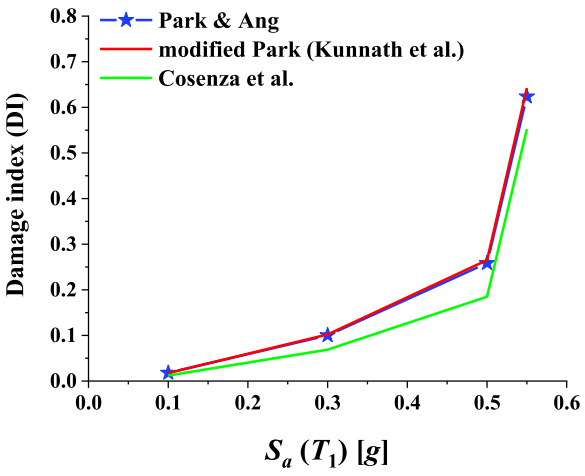

Fig. 22 Comparison of various damage indexes for the 8-story RC MRF considering pounding effect without minimum separation distance subjected to, a ground motion no. 13, $\mathbf{b}$ ground motion no. 17

(a)

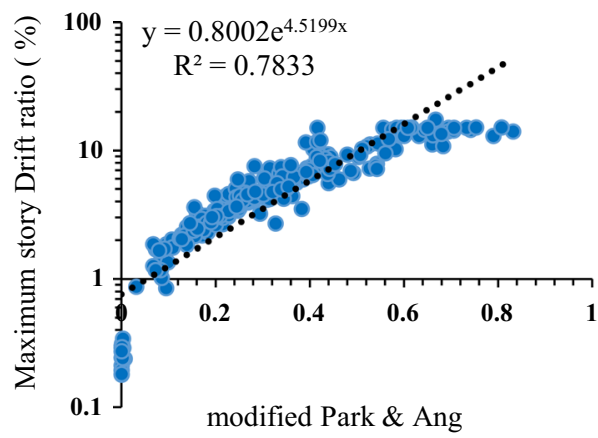

(b)

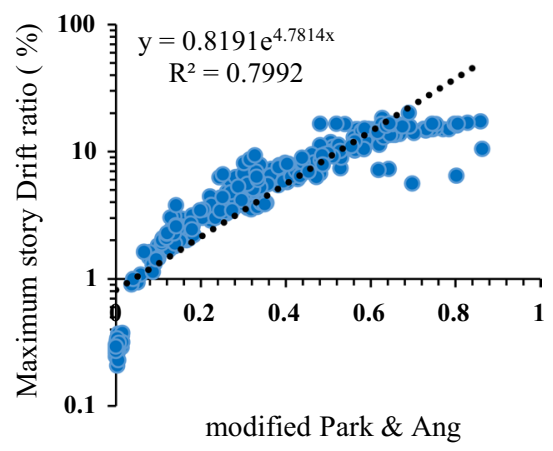

(c)

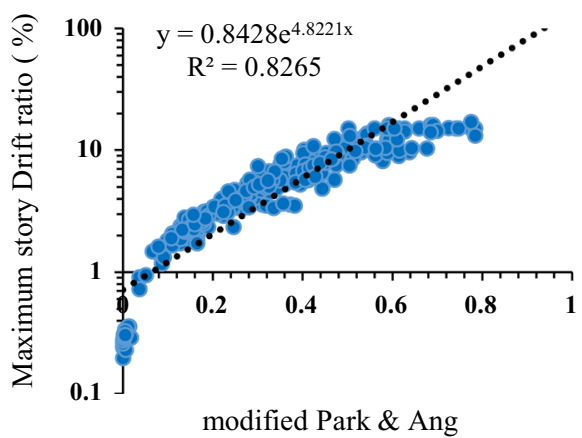

Fig. 23 Comparison of the coefficient of determination for the 4-story RC MRF subjected to 44 far-field ground motions considering pounding effects: a without minimum separation distance (b) with $60 \%$ of minimum separation distance, $\mathbf{c}$ with $100 \%$ of minimum separation distance 
(a)

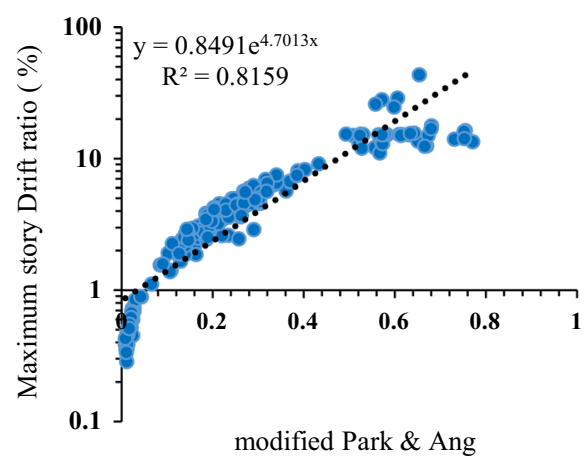

(c)

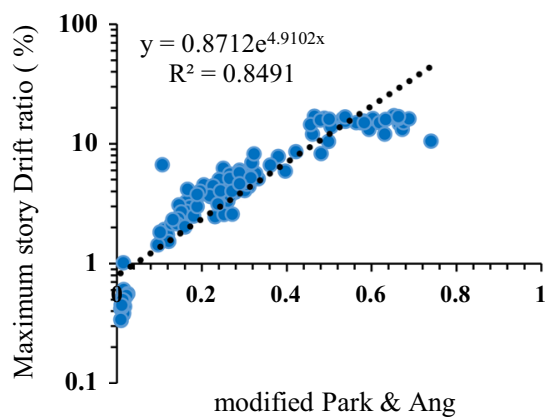

(b)

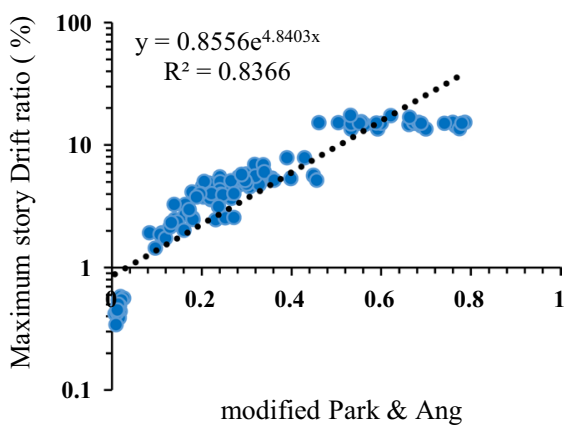

(d)

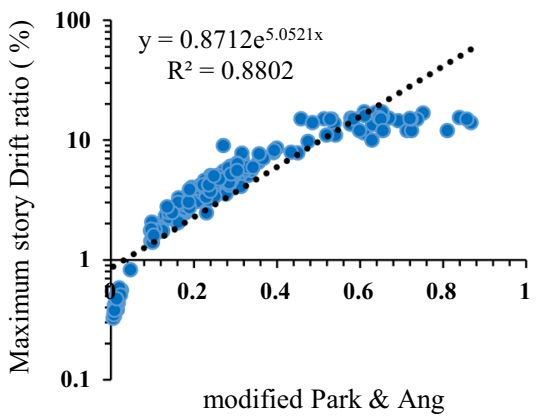

Fig. 24 Comparison of the coefficient of determination for the 8-story RC MRF subjected to 44 far-field ground motions considering pounding effects: a without minimum separation distance b with $60 \%$ of minimum separation distance $\mathbf{c}$ with $75 \%$ of minimum separation distance, $\mathbf{d}$ with $100 \%$ of minimum separation distance

hand, the MRF is damaged under lower seismic intensities than the state of pounding with a minimum separation distance. Therefore, considering a minimum separation distance leads to the improvement of the situation. Furthermore, comparing the damage indexes for 4- and 8-story RC MRFs considering pounding effect with minimum separation distance (Figs. 17a vs. 19a, 17b vs. 19b) and without minimum separation distance (Figs. 20a vs. 22a, 20b vs. 22b) under the same earthquakes and the same value of $S_{a}$, it can be seen that the damage indexes of the shorter structure are larger than values for the taller structure.

According to the aforementioned results, the modified Park \& Ang damage index, due to larger differences for different damage states $\left(S_{a}\left(T_{1}\right)\right)$, is more sensitive to seismic damages. In addition, as it can be observed from Figs. 23 and 24 considering a minimum separation distance between two adjacent MRFs (4- and 8-story) leads to the increase in the $R^{2}$ value of maximum story drift ratio versus the modified Park \& Ang damage index. On the other hand, considering $60 \%$ and $100 \%$ of $\delta_{M T}$ for the 4-story RC MRF improves the $R^{2}$ value up to $2.03 \%$ and $5.51 \%$, respectively. In addition, considering $60 \%, 75 \%$ and $100 \%$ of $\delta_{M T}$ for the 8-story RC MRF improves the $R^{2}$ value up to $2.54 \%, 4.06 \%$ and $7.88 \%$, respectively, and the correlation between these two parameters increases. 
(a)

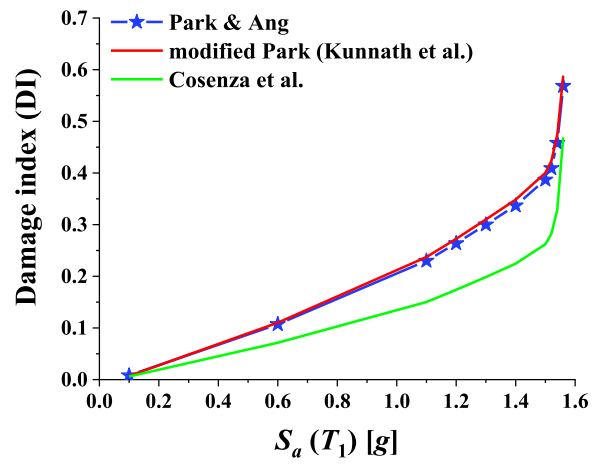

(b)

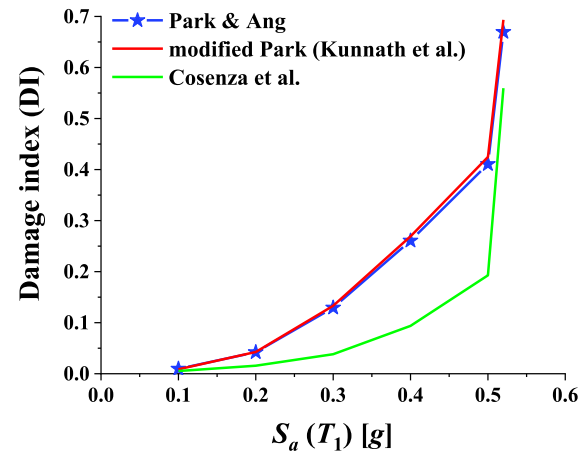

Fig. 25 Comparison of various damage indexes for the 4-story RC MRF (alone) subjected to, a ground motion no. 13 , b ground motion no. 17

(a)

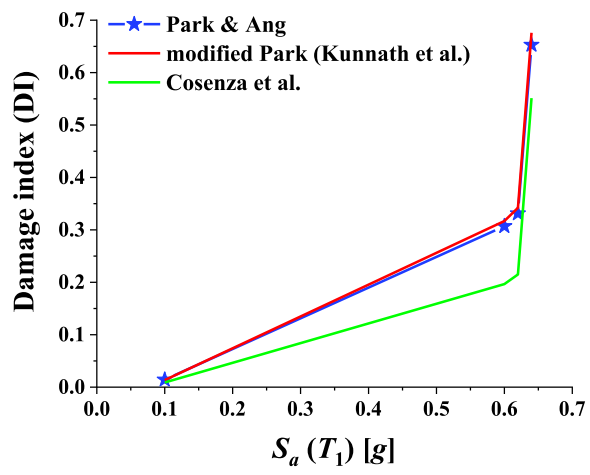

(b)

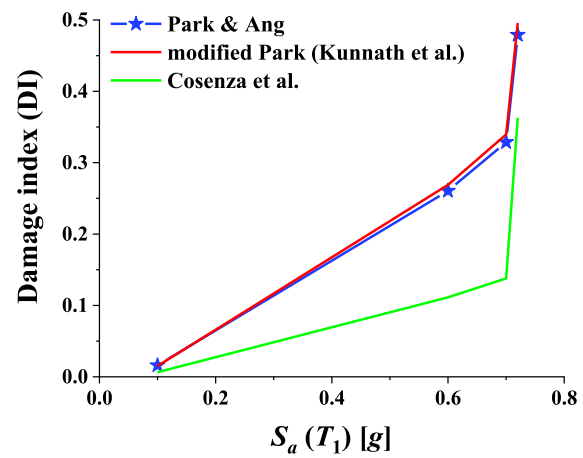

Fig. 26 Comparison of various damage indexes for the 8-story RC MRF (alone) subjected to, a ground motion no. 13, b ground motion no. 17

Comparison of the results for 4- and 8-story MRFs without pounding effects (independent vibrations) with those considering pounding show that the behavior of the MRFs considering pounding effects with a minimum separation distance are near to those of MRFs without pounding effects. This issue leads to a more accurate prediction of the behavior of MRFs (see Fig. 25 and 26 and compare with those of pounding effects in the previous sections).

\section{Conclusions}

In this article, three damage indexes have been considered for nonlinear damage detection in adjacent RC structures considering pounding effects. Some illustrative benchmark structures including 2- and 4-story as well as 4- and 8-story RC MRFs have been analyzed using IDA analyses under 44 far-field earthquake records. Pounding between RC MRFs has been considered with $60 \%, 75 \%$, and $100 \%$ of the minimum separation distance and compared 
to the case when structures vibrate independently. The following conclusions can be drawn from the study:

- Comparison of the results between the MRFs with and without considering pounding effects show that collisions lead to a decrease in the values of coefficient of determination and the nonlinear damage occurs under lower seismic intensity.

- Considering a smaller separation distance leads to an increase in the value of the coefficient of determination.

- The first nonlinear damage, and also the state of collapse, can be detected at the specified seismic intensity.

- Due to larger differences for different damage states, the modified Park \& Ang damage index is more sensitive to seismic damages and this damage index also shows larger values, as compared to other damage indicators. On the other hand, it can be concluded that while the trend of changes in all three damage indexes is similar, the modified Park $\&$ Ang damage index is on average $28.5 \%$ larger than the Cosenza damage index and $3.7 \%$ larger than the Park \& Ang damage index.

- Considering the minimum separation distance between two adjacent MRFs leads to an increase in the value of the coefficient of determination for the maximum story drift ratio versus modified Park \& Ang damage index. Also, by increasing the separation distance between two adjacent structures from 0 to $100 \%$ of the minimum separation distance, the damage index is generally decreased.

- By examining and comparing the values of the damage index for different separation distances between two adjacent MRFs, it can be observed that the rate of a variety of the damage index is low and insufficient in the range of $0 \%$ to $75 \%$ of the minimum separation distance. On the other hand, the maximum reduction in the damage index is in the range of $75 \%$ to $100 \%$ of the minimum separation distance. These results emphasize the importance and necessity of considering the minimum separation distances between two adjacent MRFs so as to reduce the damages.

- Due to pounding, shorter RC MRFs are damaged more significantly than the taller structures. On the other hand, the shorter RC MRFs (structures with smaller natural period) have high values of damage indexes.

Funding No funding was obtained.

Code availability Not applicable.

\section{Declarations}

Conflict of interest The authors declare no conflict of interest.

Data availability Paper contains all data used in the study.

Open Access This article is licensed under a Creative Commons Attribution 4.0 International License, which permits use, sharing, adaptation, distribution and reproduction in any medium or format, as long as you give appropriate credit to the original author(s) and the source, provide a link to the Creative Commons licence, and indicate if changes were made. The images or other third party material in this article are included in the article's Creative Commons licence, unless indicated otherwise in a credit line to the material. If material is not included in the article's Creative Commons licence and your intended use is not 
permitted by statutory regulation or exceeds the permitted use, you will need to obtain permission directly from the copyright holder. To view a copy of this licence, visit http://creativecommons.org/licenses/by/4.0/.

\section{References}

Al-Amawee AH, Salman MM (2006) The ratio between static and dynamic modulus of elasticity in normal and high strength concrete. J Eng Sustain Dev 10(2):163-174

Alhaddad MS, Wazira KM, Al-Salloum YA, Abbas H (2015) Ductility damage indices based on seismic performance of RC frames. Soil Dyn Earthq Eng 77:226-237

Altoontash A (2004) Simulation and damage models for performance assessment of reinforced concrete beam-column joints. Stanford University, Stanford, California

Anagnostopoulos S, Karamaneas C (2008) Use of collision shear walls to minimize seismic separation and to protect adjacent buildings from collapse due to earthquake-induced pounding. Earthquake Eng Struct Dynam 37(12):1371-1388

Anagnostopoulos SA (1988) Pounding of buildings in series during earthquakes. Earthquake Eng Struct Dynam 16(3):443-456

ASCE, AS (2002) Minimum design loads for buildings and other structures: 21-80

Baltzopoulos G, Baraschino R, Iervolino I (2019) On the number of records for structural risk estimation in PBEE. Earthquake Eng Struct Dynam 48(5):489-506

Barros RC, Khatami SM (2013) Damping ratios for pounding of adjacent building and their consequence on the evaluation of impact forces by numerical and experimental models. Mecanica Exp 22:119-131

Barros RC, Naderpour H, Khatami SM, Mortezaei AR (2013) Influence of seismic pounding on RC buildings with and without base isolation system subject to near-fault ground motions. J Rehabil Civil Eng 1(1):39-52

Bracci J, Reinhorn A, Mander J, Kunnath SK (1989) Deterministic model for seismic damage evaluation of reinforced concrete structures. National Center for Earthquake Engineering Research, Technical Report NCEER-89-0033, State University of New York at Buffalo

Cosenza E, Manfredi G, Ramasco R (1993) The use of damage functionals in earthquake engineering: a comparison between different methods. Earthquake Eng Struct Dynam 22(10):855-868

Deierlein G, Haselton C (2005) Benchmarking the Collapse Safety of Code-Compliant Reinforced Concrete Moment Frame Building Systems. ATC/JSCA US-Japan Workshop on Improvement of Structural Design and Construction Practices, Proceedings of an International Workshop

DesRoches R, Muthukumar S (2002) Effect of pounding and restrainers on seismic response of multipleframe bridges. J Struct Eng 128:860-869

Efraimiadou S, Hatzigeorgiou GD, Beskos DE (2013a) Structural pounding between adjacent buildings subjected to strong ground motions. Part I: the effect of different structures arrangement. Earthquake Eng Struct Dyn 42(10):1509-1528

Efraimiadou S, Hatzigeorgiou GD, Beskos DE (2013b) Structural pounding between adjacent buildings subjected to strong ground motions. Part II: the effect of multiple earthquakes. Earthquake Eng Struct Dyn 42(10):1529-1545

Elwardany H, Jankowski R, Seleemah A (2021) Mitigating the seismic pounding of multi-story buildings in series using linear and nonlinear fluid viscous dampers. Arch Civil Mech Eng 21(4):137

Elwardany H, Seleemah A, Jankowski R (2017) Seismic pounding behavior of multi-story buildings in series considering the effect of infill panels. Eng Struct 144:139-150

Elwardany H, Seleemah A, Jankowski R, El-Khoriby S (2019) Influence of soil-structure interaction on seismic pounding between steel frame buildings considering the effect of infill panels. Bull Earthq Eng 17(11):6165-6202

Ghobarah A, Abou-Elfath H, Biddah A (1999) Response-based damage assessment of structures. Earthquake Eng Struct Dynam 28(1):79-104

Goldsmith W (1960) Impact: The Theory and Physical Behaviour of Colliding Solids. London, UK: Edward Arnold

Hanganu AD, Onate E, Barbat AH (2002) A finite element methodology for local/global damage evaluation in civil engineering structures. Comput Struct 80(20-21):1667-1687

Huang W, Zou M, Qian J, Zhou Z (2018) Consistent damage model and performance-based assessment of structural members of different materials. Soil Dyn Earthq Eng 109:266-272

Ibarra LF, Krawinkler H (2005) Global Collapse of Frame Structures Under Seismic Excitations: Pacific Earthquake Engineering Research Center Berkeley, CA 
Ibarra LF, Medina RA, Krawinkler H (2005) Hysteretic models that incorporate strength and stiffness deterioration. Earthquake Eng Struct Dynam 34(12):1489-1511

IBC (2003). International Building Code (IBC), International Code Council (ICC). IL, USA

Jankowski R (2010) Experimental study on earthquake-induced pounding between structural elements made of different building materials. Earthquake Eng Struct Dynam 39(3):343-354

Jankowski R (2012) Non-linear FEM analysis of pounding-involved response of buildings under nonuniform earthquake excitation. Eng Struct 37:99-105

Kamaris GS, Hatzigeorgiou GD, Beskos DE (2013) A new damage index for plane steel frames exhibiting strength and stiffness degradation under seismic motion. Eng Struct 46:727-736

Kandemir-Mazanoglu EC, Mazanoglu K (2017) An optimization study for viscous dampers between adjacent buildings. Mech Syst Signal Process 89:88-96

Kazemi F, Miari M, Jankowski R (2021a) Investigating the effects of structural pounding on the seismic performance of adjacent RC and steel MRFs. Bull Earthq Eng 19(1):317-343

Kazemi F, Mohebi B, Jankowski R (2021b) Predicting the seismic collapse capacity of adjacent SMRFs retrofitted with fluid viscous dampers in pounding condition. Mech Syst Signal Process 161:107939

Khatami SM, Naderpour H, Barros RC, Jankowski R (2019) Verification of formulas for periods of adjacent buildings used to assess minimum separation gap preventing structural pounding during earthquakes. Adv Civil Eng 2019:9714939

Khatiwada S, Chouw N, Butterworth JW (2013) Evaluation of numerical pounding models with experimental validation. Bull N Z Soc Earthq Eng 46(3):117-130

Kim J, Lynch JP (2012) Subspace system identification of support-excited structures-part I: theory and black-box system identification. Earthquake Eng Struct Dynam 41(15):2235-2251

Kunnath SK, Reinhorn AM, Lobo R (1992) IDARC Version 3.0: A program for the inelastic damage analysis of reinforced concrete structures

Leibovich E, Rutenberg A, Yankelevsky DZ (1996) On eccentric seismic pounding of symmetric buildings. Earthquake Eng Struct Dynam 25:219-233

Lignos DG, Krawinkler H (2010) Deterioration modeling of steel components in support of collapse prediction of steel moment frames under earthquake loading. J Struct Eng 137(11):1291-1302

Lopez-Garcia D, Soong T (2009a) Assessment of the separation necessary to prevent seismic pounding between linear structural systems. Probab Eng Mech 24(2):210-223

Lopez-Garcia D, Soong T (2009b) Evaluation of current criteria in predicting the separation necessary to prevent seismic pounding between nonlinear hysteretic structural systems. Eng Struct 31(5):1217-1229

Mahmoud S, Jankowski R (2009) Elastic and inelastic multi-storey buildings under earthquake excitation with the effect of pounding. J Appl Sci 9(18):3250-3262

Mahmoud S, Chen X, Jankowski R (2008) Structural pounding models with Hertz spring and nonlinear damper. J Appl Sci 8(10):1850-1858

Mahmoud S, Jankowski R (2011) Modified linear viscoelastic model of earthquake-induced structural pounding. Iran J Sci Technol Trans Civil Eng 35:51-62

McKenna F, Fenves G, Filippou F (2010) OpenSees. University of California, Berkeley

Miari M, Choong KK, Jankowski R (2019) Seismic pounding between adjacent buildings: Identification of parameters, soil interaction issues and mitigation measures. Soil Dyn Earthq Eng 121:135-150

Miari M, Choong KK, Jankowski R (2021) Seismic pounding between bridge segments: a state-of-the-art review. Arch Comput Methods in Eng 28(2):495-504

Mohebi B, Chegini AHT, Miri ART (2019) A new damage index for steel MRFs based on incremental dynamic analysis. J Constr Steel Res 156:137-154

Moustafa A, Mahmoud S (2014) Damage assessment of adjacent buildings under earthquake loads. Eng Struct 61:153-165

Muthukumar S, DesRoches R (2006) A Hertz contact model with non-linear damping for pounding simulation. Earthquake Eng Struct Dynam 35(7):811-828

Naderpour H, Barros RC, Khatami SM (2015) A study of pounding to simulate impact and determine the impact damping ratio. In: Paper presented at the proceedings of the fifteenth international conference on civil. Structural and Environmental Engineering Computing, Prague, Czech Republic

Naderpour H, Barros RC, Khatami SM, Jankowski R (2016) Numerical study on pounding between two adjacent buildings under earthquake excitation. Shock Vib 2016:1504783

Naderpour H, Khatami SM (2015) A new model for calculating the impact force and the energy dissipation based on CR-factor and impact velocity. Scientia Iranica 22(1):59-68

Naderpour H, Khatami SM, Barros RC (2017) Prediction of critical distance between two MDOF systems subjected to seismic excitation in terms of artificial neural networks. Period Polytech Civil Eng 61(3):516-529 
Nie GN, Zhang C-X, Zhi X-D, Dai J (2017) Damage quantification, damage limit state criteria and vulnerability analysis for single-layer reticulated shell. Thin-Walled Struct 120:378-385

Overschee PV, Moor BD (1994) N4SID: subspace algorithms for the identification of combined deterministic-stochastic systems. Automatica 30(1):75-93

Pang R, Xu B, Kong X, Zou D (2018) Seismic fragility for high CFRDs based on deformation and damage index through incremental dynamic analysis. Soil Dyn Earthq Eng 104:432-436

Park Y-J, Ang AH-S (1985) Mechanistic seismic damage model for reinforced concrete. J Struct Eng 111(4):722-739

Polycarpou PC, Papaloizou L, Komodromos P (2014) An efficient methodology for simulating earthquakeinduced 3D pounding of buildings. Earthquake Eng Struct Dynam 43(7):985-1003

Reinhorn A, Roh H, Sivaselvan M, Kunnath S, Valles R, Madan A, Park Y (2009) IDARC 2D version 7.0: user's guide of a program for the inelastic damage analysis of buildings. Buffalo, New York

Rezaei H, Moayyedi SA, Jankowski R (2020) Probabilistic seismic assessment of RC box-girder highway bridges with unequal-height piers subjected to earthquake-induced pounding. Bull Earthq Eng 18(4):1547-1578

Rosenblueth E, Meli R (1986) The 1985 Mexico earthquake. Concr Int 8(5):23-34

Ruangrassamee A, Kawashima K (2001) Relative displacement response spectra with pounding effect. Earthquake Eng Struct Dynam 30:1511-1538

Sharifi A, Banan M-R, Banan M-R (2012) A strain-consistent approach for determination of bounds of ductility damage index for different performance levels for seismic design of RC frame members. Eng Struct 37:143-151

Sołtysik B, Jankowski R (2013) Non-linear strain rate analysis of earthquake-induced pounding between steel buildings. Int J Earth Sci Eng 6(3):429-433

Sołtysik B, Jankowski R (2015) Building damage due to structural pounding during earthquakes. J Phys: Conf Ser 628:012040

Sołtysik B, Jankowski R (2016) Earthquake-induced pounding between asymmetric steel buildings. Seismic Behaviour and Design of Irregular and Complex Civil Structures II, Geotechnical, Geological and Earthquake Engineering 40 255-261

Tubaldi E, Barbato M, Ghazizadeh S (2012) A probabilistic performance-based risk assessment approach for seismic pounding with efficient application to linear systems. Struct Saf 36-37:14-22

Yaghmaei-Sabegh S, Jalali-Milani N (2012) Pounding force response spectrum for near-field and far-field earthquakes. Scientia Iranica 19(5):1236-1250

Yazdanpanah O, Mohebi B, Yakhchalian M (2020a) Selection of optimal wavelet-based damage-sensitive feature for seismic damage diagnosis. Measurement 154:107447

Yazdanpanah O, Mohebi B, Yakhchalian M (2020b) Seismic damage assessment using improved waveletbased damage-sensitive features. J Build Eng 31:101311

Publisher's Note Springer Nature remains neutral with regard to jurisdictional claims in published maps and institutional affiliations. 